\title{
A IMAGEM QUE PERMANECE, A NARRATIVA QUE INTERPRETA: ESTUDO ANTROPOLÓGICO DA MEMÓRIA AFETIVA DA GUARDIÃ DOS RETRATOS DE FAMÍLIA ${ }^{1}$
}

\author{
Leandra Mylius \\ Cornelia Eckert (Orientação)
}

\section{Introdução}

Esta pesquisa consiste num estudo de antropologia visual sobre "retratos de família". Trata-se da classificação e análise de uma coleção de fotografias referentes a duas linhagens familiares: Roca e Barcellos.

Considerando a fotografia histórica como um "dado antropológico", a análise de fotos de família, buscando perceber qual o estatuto da fotografia para o grupo pesquisado, de que maneira estas imagens acionam a memória dos descendentes das pessoas retratadas e quais as representações sobre família para o grupo em questão, apresentadas a partir das imagens.

Dois fatos determinaram a realização deste trabalho: em primeiro lugar, tenho desenvolvido atividades junto ao Núcleo de Antropologia Visual da UFRGS, tendo participado de cursos e oficinas sobre a utilização da fotografia na pesquisa antropológica, despertando o interesse sobre o tema. Em segundo lugar, houve uma doação de fotografias de família para o Banco de Imagens e Efeitos Visuais ${ }^{3}$. Isto nos incentivou a tomar este material como objeto de estudo antropológico sobre o tema memória e família.

Realizou-se, então, um estudo etnográfico sobre esses retratos de família. Para desenvolver esta pesquisa contatamos a doadora dos retratos, Daisy Macedo de Barcellos, professora do Departamento de Antropologia da Universidade Federal do Rio Grande do Sul, que concordou em colaborar com nossa pesquisa, analisando as imagens, identificando os retratos e narrando a história familiar. Além das fotografias doadas ao Banco de Imagens e Efeitos Visuais, tivemos acesso à coleção fotográfica da família Roca e Barcellos, atualmente aos cuidados de Daisy, e que abrange quatro gerações destas famílias.

\footnotetext{
${ }^{1}$ Trabalho de Conclusão do Curso de Ciências Sociais da Universidade Federal do Rio Grande do Sul, ano de 2000, realizado sob orientação da Profa. Dra. Cornelia Eckert.

${ }^{2}$ Expressão utilizada pelo antropólogo e fotógrafo Milton Guran para mostrar a importância da utilização da fotografia no trabalho antropológico, não apenas como material ilustrativo do texto, mas como um instrumento que viabiliza a reflexão de como os indivíduos ou grupos sociais representam, organizam e classificam suas experiências.

${ }^{3}$ O Projeto Banco de Imagens e Efeitos Visuais, coordenado pela antropóloga $\operatorname{Dr}^{\mathrm{a}}$ Ana Luiza Carvalho da Rocha e pela prof ${ }^{a}$. Dr ${ }^{a}$ Cornelia Eckert, faz parte do Laboratório de Antropologia Social do PPGAS/UFRGS.
} 
Embora considere que o fato de estar com esse material seja circunstancial, Daisy acaba assumindo a responsabilidade de selecioná-lo, definindo quais as fotografias guardará consigo, as quais constituirão a coleção da família, e quais doará para seus parentes, descendentes diretos da pessoa retratada. Convém assinalar que foi no processo de préselecionar este material fotográfico, que Daisy decidiu doar parte da coleção para o Banco de Imagens e Efeitos Visuais.

Neste sentido, estamos considerando Daisy como "guardiã da memória"4 familiar. Isto ocorre por dois motivos: primeiro por ela ser a descendente responsável por esta coleção fotográfica, conservando, selecionando e classificando o material; segundo, por ser a narradora da história da família, reconstruindo o passado a partir destas imagens.

Não se trata unicamente de uma memória individual, como esclarece Maurice Halbwachs: “... se a memória coletiva tira sua força e sua duração do fato de ter por suporte um conjunto de homens, não obstante eles são indivíduos que se lembram, enquanto membros do grupo... Diríamos voluntariamente que cada memória individual é um ponto de vista sobre a memória coletiva, que este ponto de vista muda conforme o lugar que ali eu ocupo, e que este lugar mesmo muda segundo as relações que mantenho com outros meios" (Halbwachs, 1990: 51).

A partir de uma primeira análise e classificação do material, desenvolvemos três sessões de entrevistas com a Daisy, no período de outubro a novembro de 2000, na cidade de Porto Alegre. As entrevistas foram gravadas e transcritas, constituindo, juntamente com as fotografias, a base do nosso estudo.

Ao propor a análise de fotografias históricas, estamos considerando a importância de compreender o contexto onde esta imagem foi produzida. Neste sentido, o testemunho de Daisy possibilitou que as imagens analisadas fossem apreendidas a partir de um “trabalho de memória”. Segundo Bosi, "na maior parte das vezes, lembrar não é reviver, mas refazer, reconstruir, repensar, com imagens e idéias de hoje, as experiências do passado. A memória não é sonho, é trabalho" (Bosi, 1987:17).

Nesta perspectiva, Daisy narra a história da família a partir da sua lembrança reconstruída no presente e é justamente a sua disposição de se colocar como narradora que nos permite, a partir da sua fala e das imagens analisadas, compreender a trajetória histórica desta família.

\footnotetext{
${ }^{4}$ Termo proposto por Maurice Halbwachs (1990).
} 
As entrevistas foram realizadas na residência da Daisy. Ocorreram na sala de estar onde as fotografias foram colocadas sobre uma mesa à nossa frente. Solicitei que Daisy contasse como essa coleção fotográfica foi constituída e por que estava aos seus cuidados. Depois olhamos foto por foto. Neste momento Daisy falou livremente sobre cada um dos retratos. Primeiramente ela identificava a fotografia, indicando as pessoas retratadas e o ano de realização da mesma. Depois, narrava livremente pequenas histórias de família a partir da imagem, contextualizando o retrato na trajetória familiar.

As fotografias não possuíam uma ordem e foram analisadas, num primeiro momento, aleatoriamente. Muitas vezes, durante a narrativa, percebíamos que um retrato remetia Daisy a outros. Isto fazia com que ela acabasse por separar algumas destas fotos das demais, reunindo, por exemplo, fotografias dos seus parentes diretos ou fotografias de pessoas com quem possuía uma relação afetiva mais intensa.

Podemos dizer que as imagens foram o ponto de partida para a reconstrução das lembranças de Daisy, representando aqui um marco na memória pois, além de acioná-la, acabam retendo, num determinado sentido, informações de um tempo vivido, dado que "não são somente os fatos, mas as maneiras de ser e de pensar de um passado, de um ontem, que se fixam na memória" (Halbwachs, 1990: 51)

Portanto, metodologicamente a pesquisa consistiu na análise das fotografias que foram reinterpretadas a partir da entrevista com a narradora da história familiar.

Além das fotografias e das entrevistas onde centramos a análise, tivemos contato com outros materiais, tais como anotações sobre a família, feitas por membros do grupo, cartões postais, santinhos trocados por ocasião de eventos religiosos, além de alguns objetos transmitidos por herança, testemunhos dos "quadros sociais" da história familiar e coletiva, como nos ensina Maurice Halbwachs.

Estes materiais referem-se às famílias que tiveram na cidade de Porto Alegre uma de suas principais referências de habitação. A família Roca veio para o Brasil por volta de 1890 procedente de Málaga, Espanha. Desde sua chegada fixou residência em Porto Alegre. Observamos que muitas vezes, a narrativa da história desta linhagem da família se cruza com a própria história da cidade de Porto Alegre ${ }^{5}$. Isto fica claro quando Daisy conta que

\footnotetext{
5 Porto Alegre, capital do Estado do Rio Grande do Sul, é uma cidade que se caracteriza por ter sido fundada por imigrantes portugueses no século XVIII.
} 
Manoel Roca, seu bisavô, foi um dos responsáveis pelo calçamento da "Rua da Praia"6 . Ao narrar a história da sua família, Daisy acaba falando da história da própria cidade.

Já o seu bisavô Antero, era descendente da família Loreto de Barcellos, linhagem familiar com origem na aristocracia portuguesa, herdeiro do título de Visconde de Loreto. A bisavó Clara, casada com Antero, era filha de Hilário Pereira Fortes, Barão de Viamão, cujo título foi concedido pela Coroa Portuguesa por serviços militares prestados ao Império. Esta origem aristocrática aparece como uma referência importante ao longo da narrativa, estabelecendo a rede de relações com outras famílias da mesma classe social na época.

A reconstituição da árvore genealógica da família da Daisy, apresentada em anexo, auxiliou na identificação do grau de parentesco de cada pessoa citada pela narradora, bem como na identificação do percurso percorrido pelas fotografias trocadas.

A rede de parentesco destas duas famílias, não se restringe à cidade de Porto Alegre. Isto ocorre em função de haver um deslocamento de alguns membros da família para cidades do interior onde fixaram residência.

Havia entre estes parentes, que moravam em cidades diferentes, uma grande troca de fotografias em forma de presentes. Isto permite que, através da análise desta coleção reinterpretada pela guardiã, se possa fazer uma reflexão sobre a fotografia como objeto de troca de reciprocidade, tendo eficácia simbólica na comunicação entre redes familiares, dinamizando redes de parentesco. Estas fotografias reforçam as relações entre os membros da rede familiar na medida em que é utilizada como objeto que serve para presentear outros membros do grupo, reafirmando os laços de pertencimento deste grupo.

Também há uma determinada circularidade de retratos com redes de amizade estabelecidas entre famílias de uma mesma posição social. Neste sentido, as fotografias não só registram o fragmento de um acontecimento passado, mas também dinamizam as relações afetivas do grupo através das trocas.

É através da coleção fotográfica da família que a narradora vai reconstruir as lembranças do passado, do grupo e do lugar habitado por este, neste caso a cidade de Porto Alegre. Ao utilizar estas imagens e associá-las à narrativa de Daisy, acabamos por constituir um instrumento que serve para acionar a nossa própria memória.

\footnotetext{
${ }^{6}$ Uma das ruas mais antigas da cidade, localizada na área central de Porto Alegre, assim denominada por "beirar" o rio Guaíba no passado. O centro que hoje conhecemos foi posteriormente aterrado. Oficialmente esta rua chama-se Rua dos Andradas, mantém o calçamento original na maior parte de sua extensão e, entre as ruas Dr. Flores e Caldas Jr. não é permitido o tráfego de veículos, ficando destinado somente para o deslocamento de pedestres. Sobre imagens desta rua, ver a exposição fotográfica intitulada "Rua da Praia", de Patrícia Rodolpho, acervo do Núcleo de Antropologia Visual/PPGAS/UFRGS.
} 
Este trabalho está estruturado em quatro partes. A primeira, "Fotografias de família”, contém parte das fotografias que analisamos na pesquisa. Ao trazer estas imagens, sugerimos que o leitor percorra os mesmos caminhos da pesquisadora e da narradora, através dos retratos.

As fotografias apresentadas nesta primeira parte estão classificadas em quatro grupos: No primeiro estão as diferentes gerações das famílias Roca e Barcellos; no segundo, apresentamos alguns retratos trocados entre os parentes e amigos da família; o terceiro representa a passagem das fotografias feitas em estúdio para as fotos ao ar livre, feitas primeiramente por fotógrafos profissionais que atuavam nas ruas e posteriormente por um membro da família com a máquina desta e finalmente apresentamos duas fotografias que retratam gerações diferentes da família, mas com imagens muito semelhantes, cujo significado atribuído pela narradora foi o mesmo: a representação da relação do pai com as filhas.

$\mathrm{Na}$ segunda parte, "a fotografia como dado etnográfico", abordamos o uso da imagem na pesquisa antropológica e na terceira, "os retratos e o movimento: circulação de imagens", tratamos da questão da reciprocidade dentro da rede familiar e de amizade, ocorrida através de trocas de retratos. Finalmente, em "fotografia e memória", abordamos a questão da fotografia enquanto instrumento que possibilita à narradora acionar a memória do grupo, contando a história familiar deste. 
Fotografias de família:

As diferentes gerações das família Roca e Barcellos
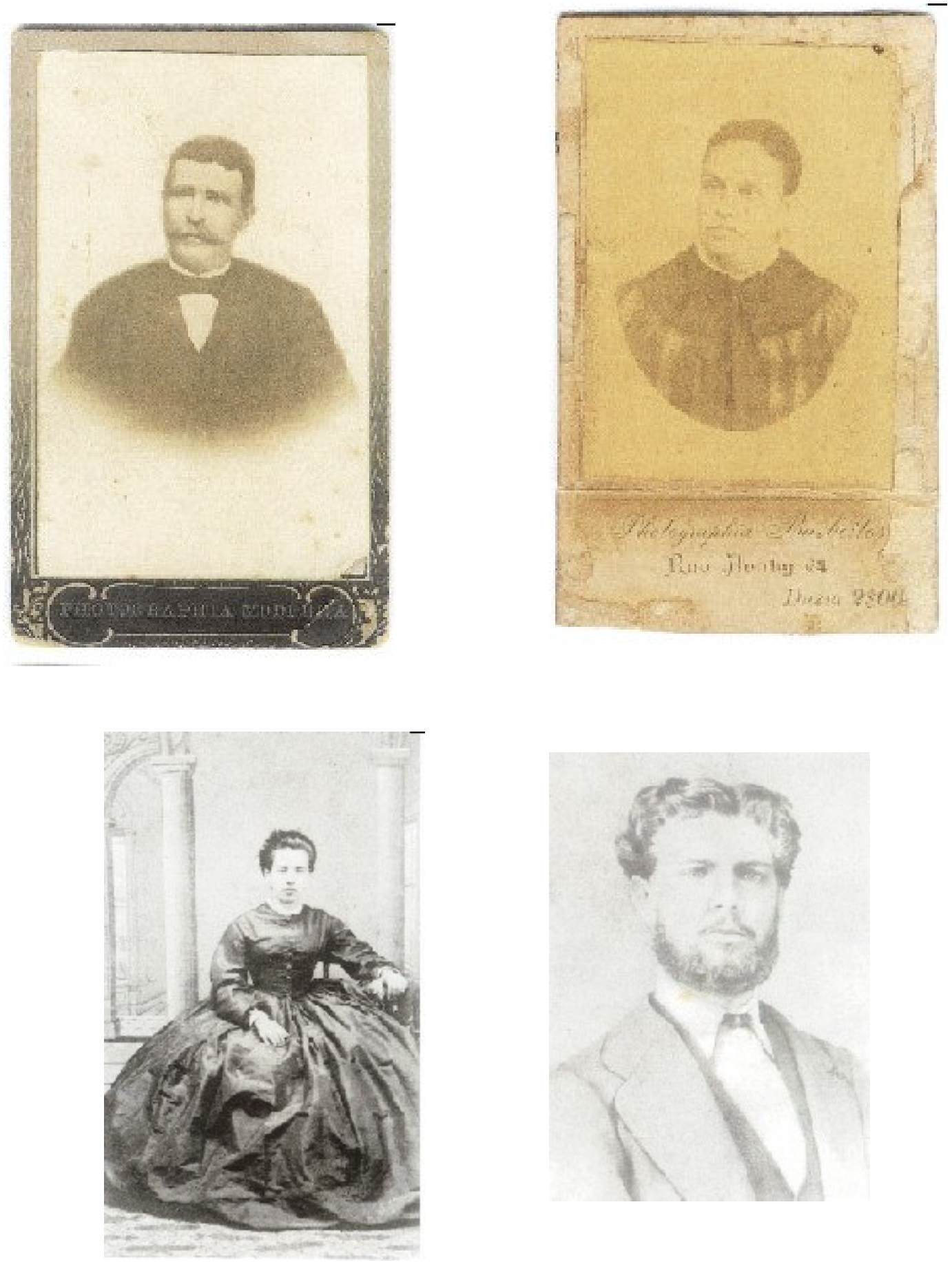


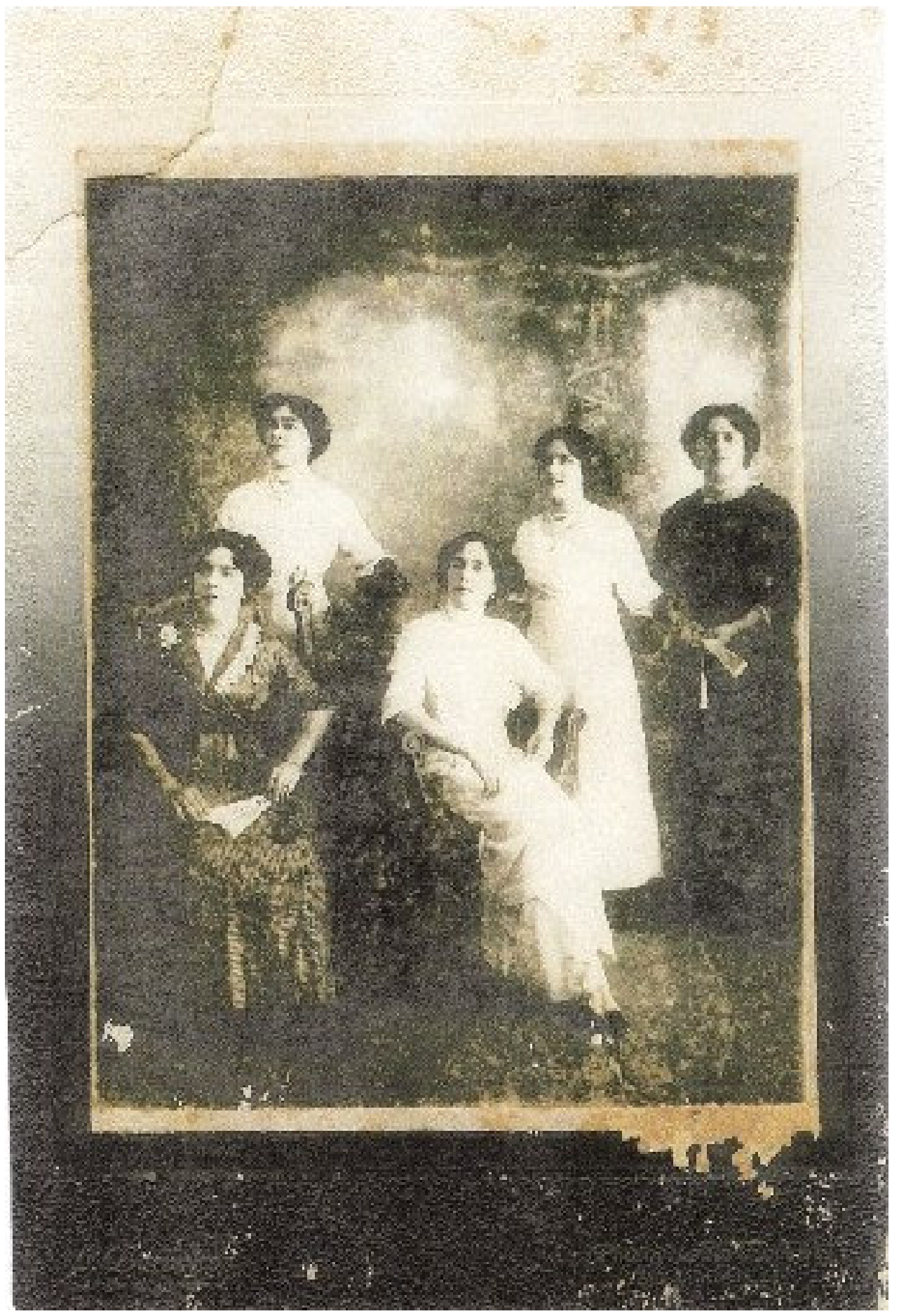



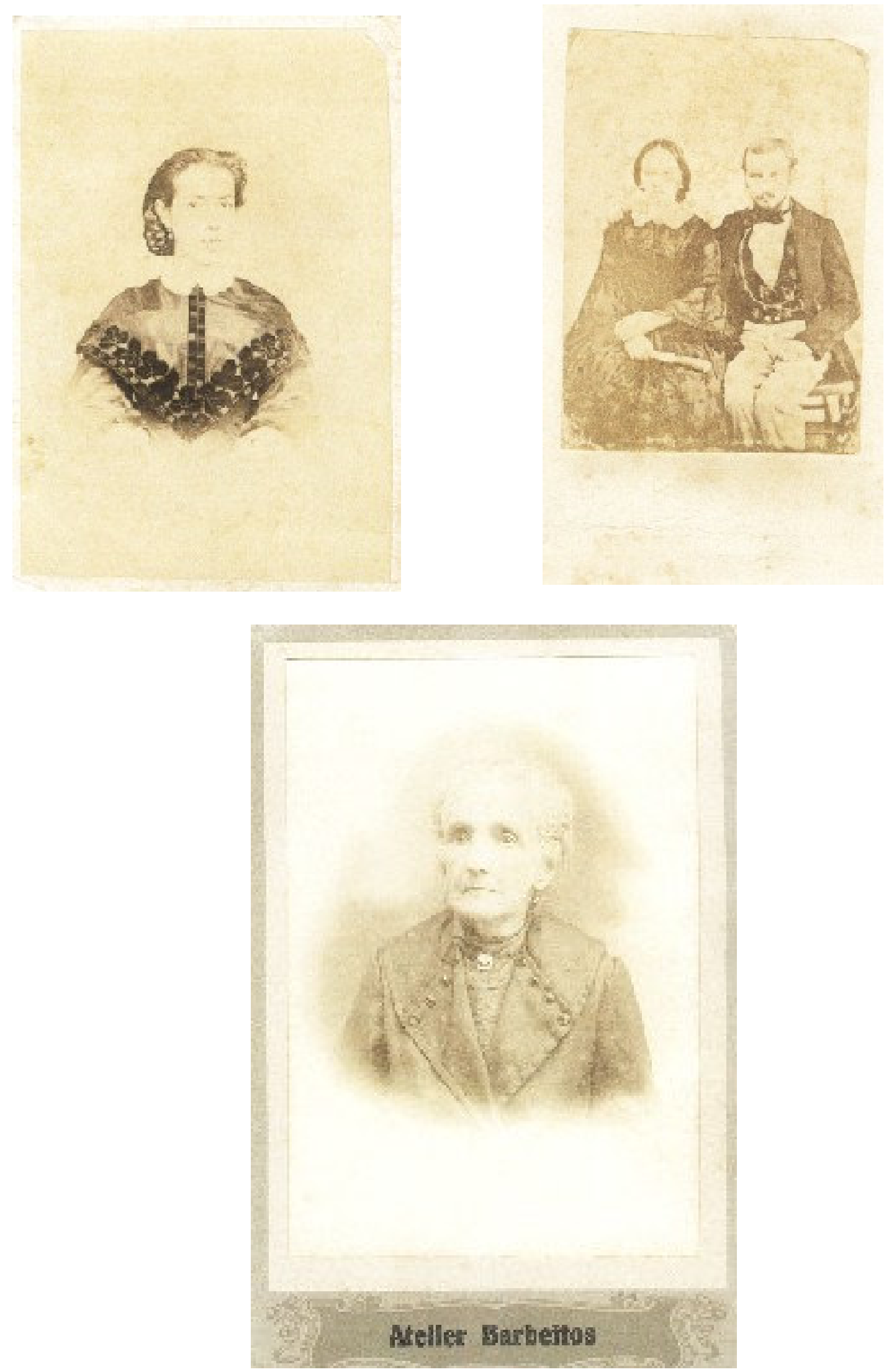

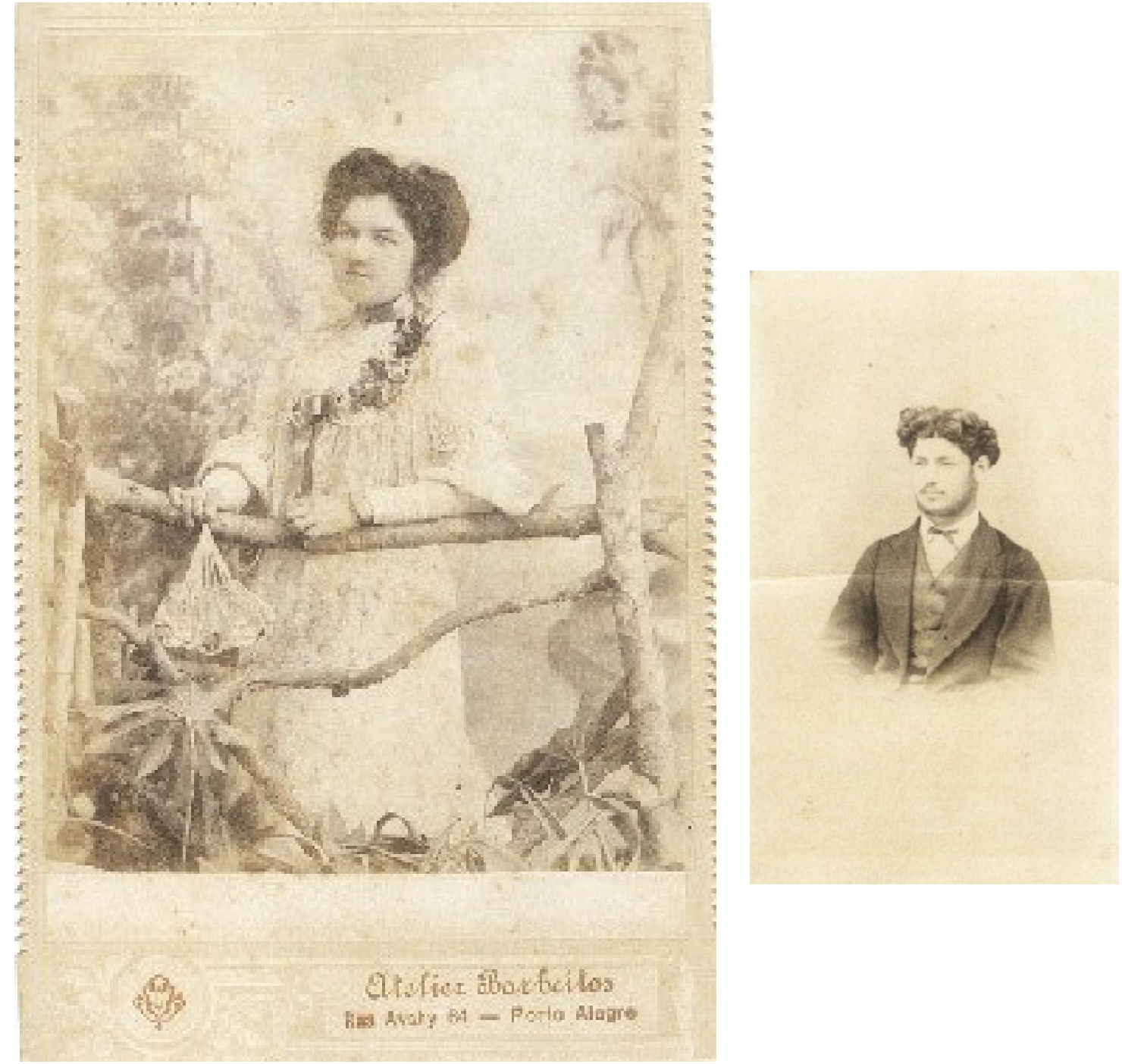


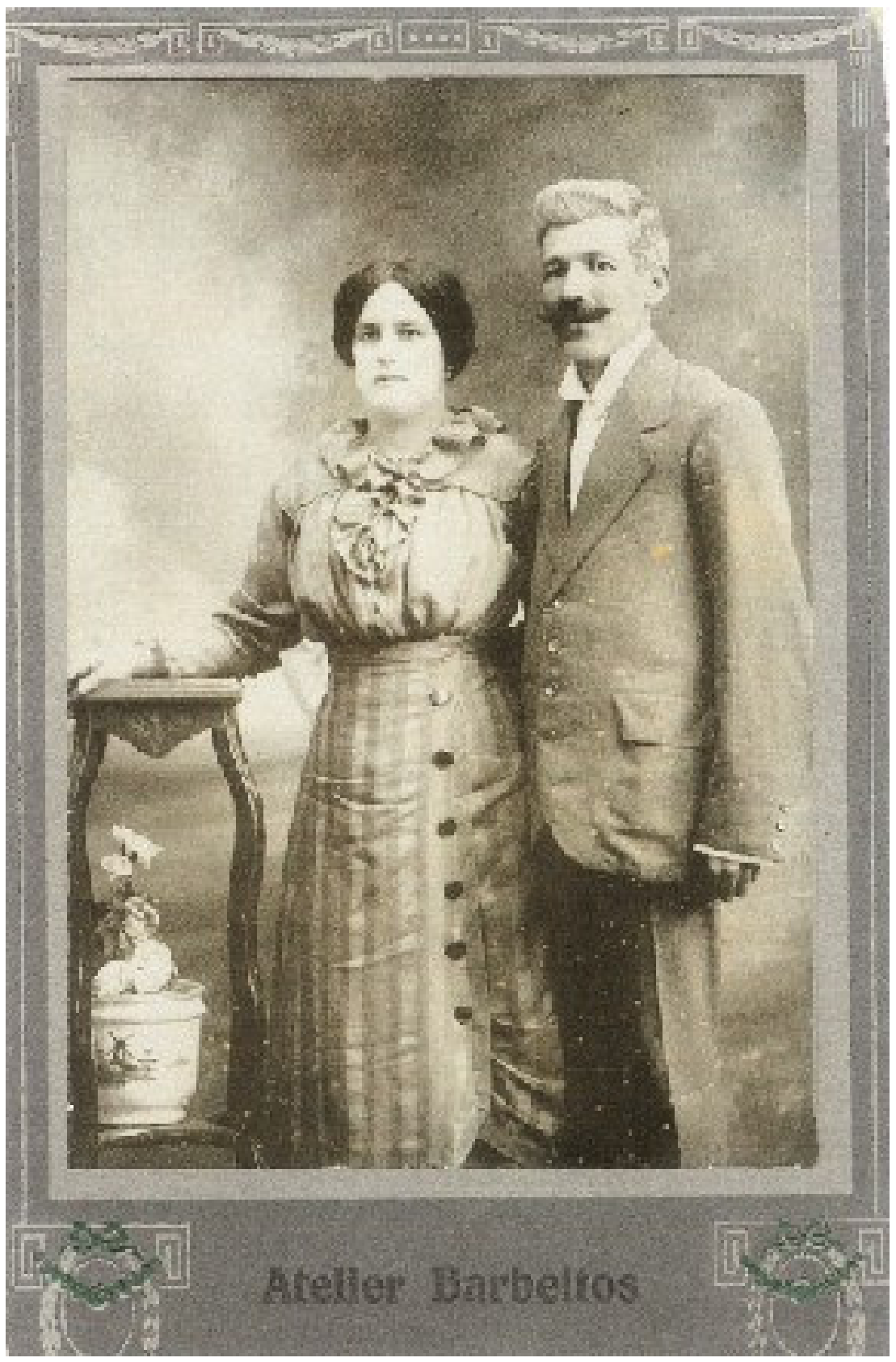



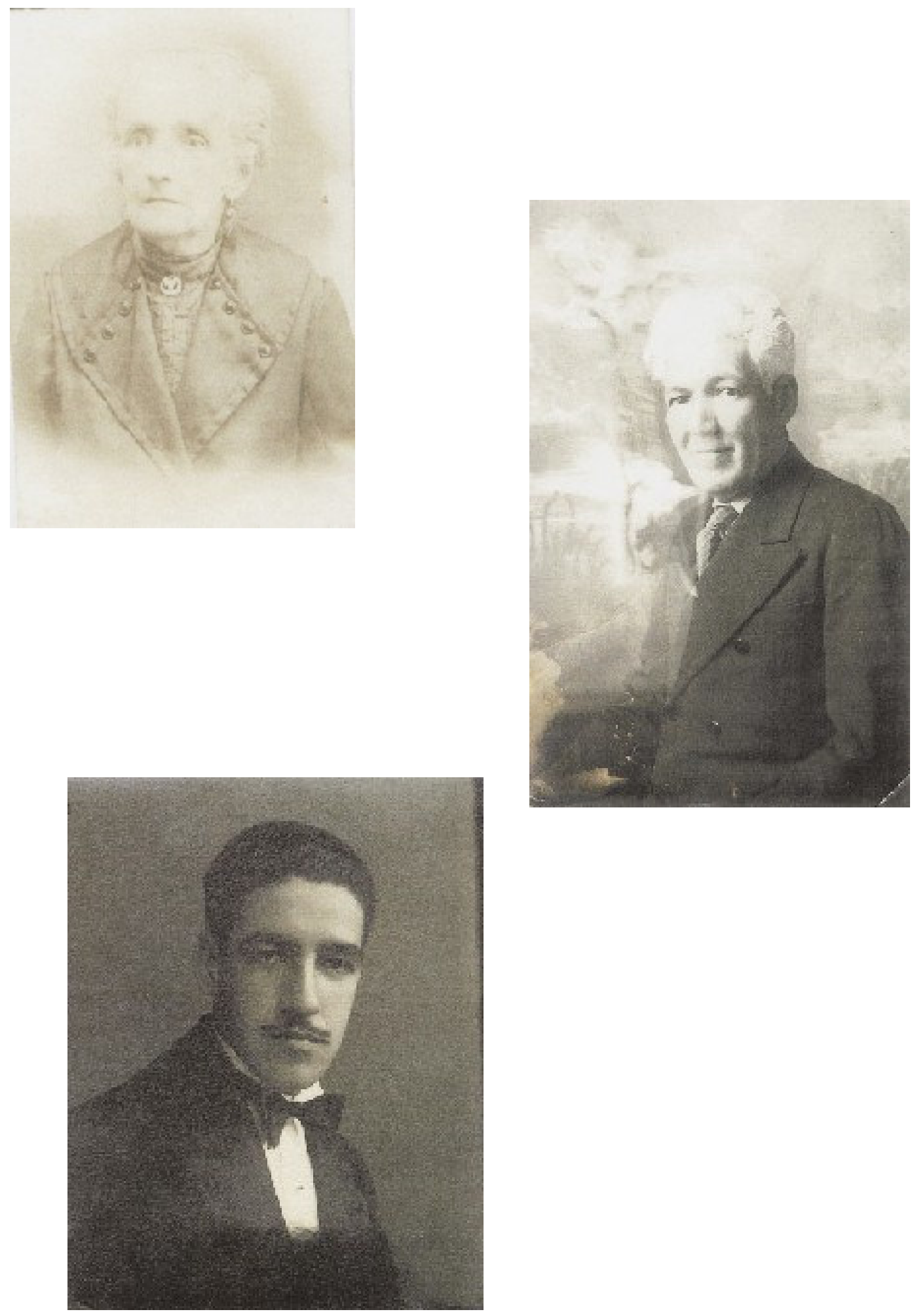

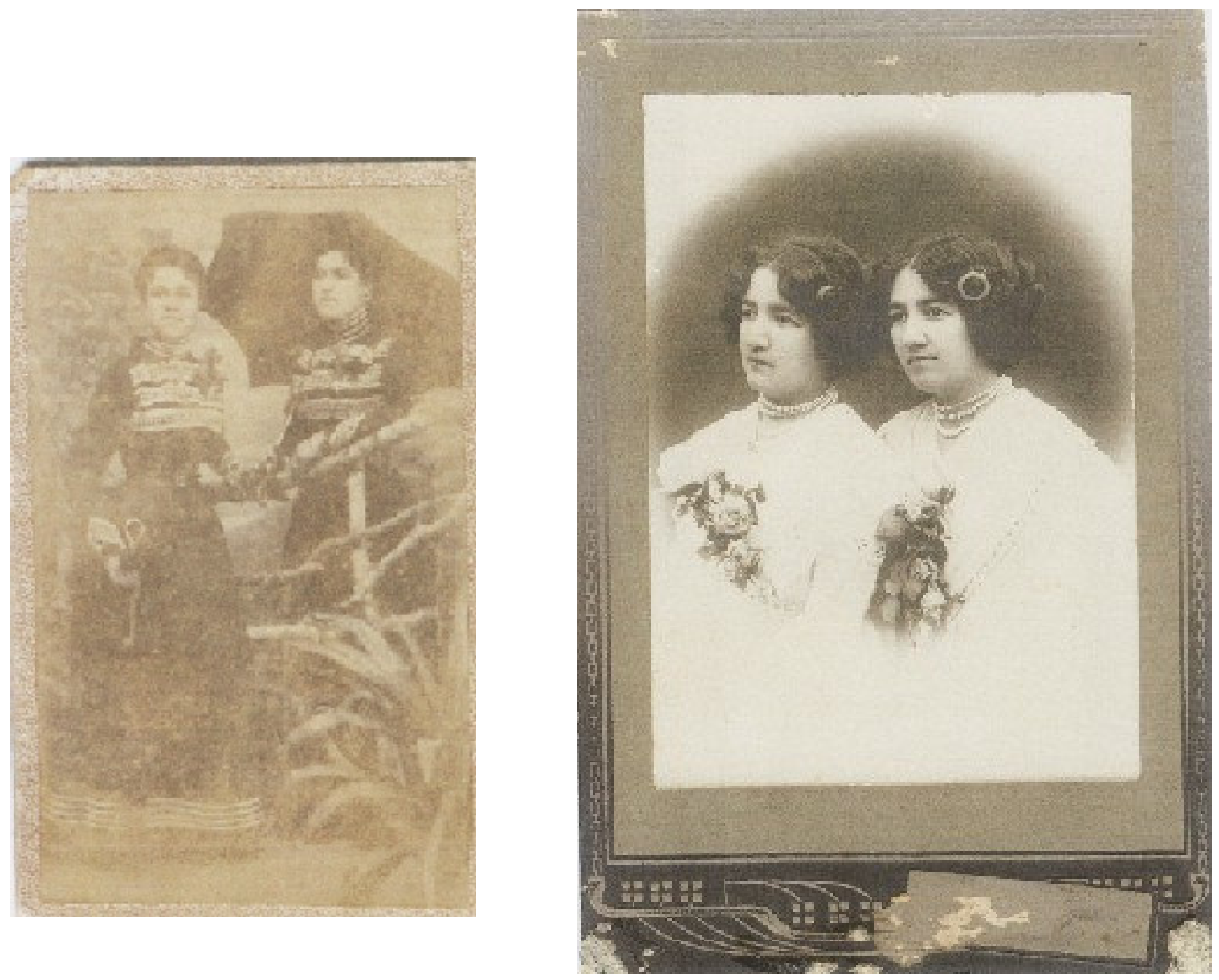


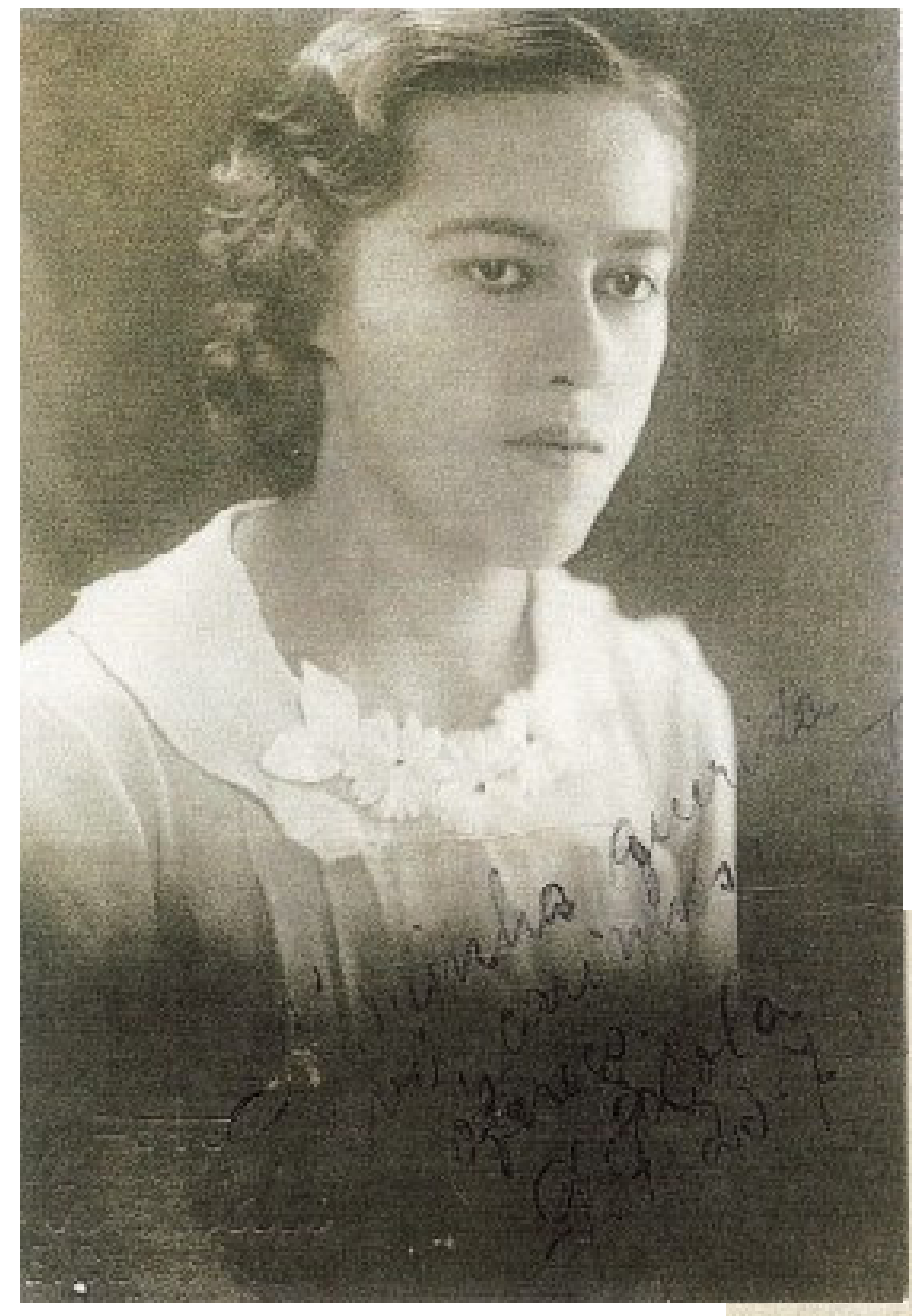



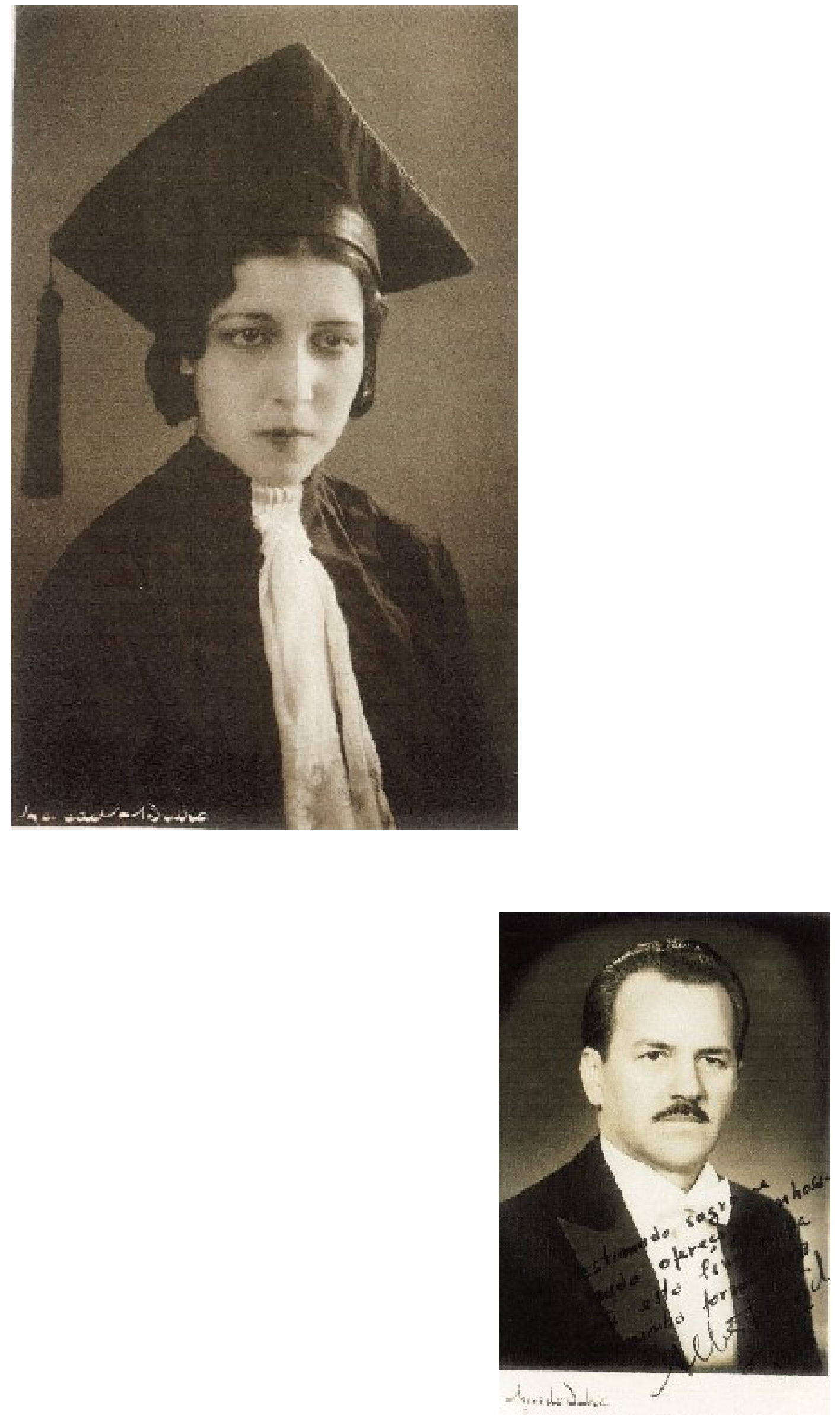

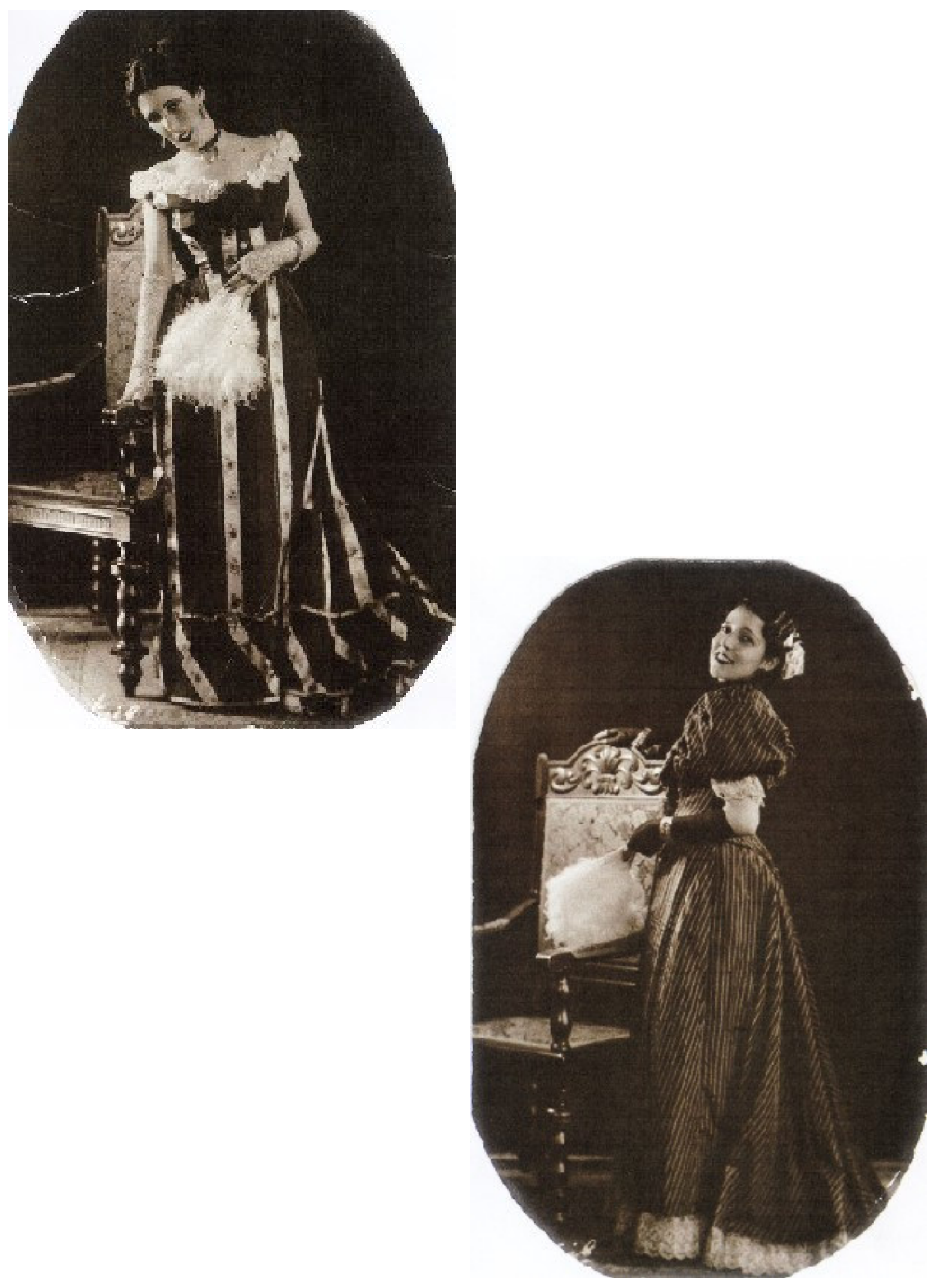
Circulação de imagens: reciprocidade através da troca de retratos
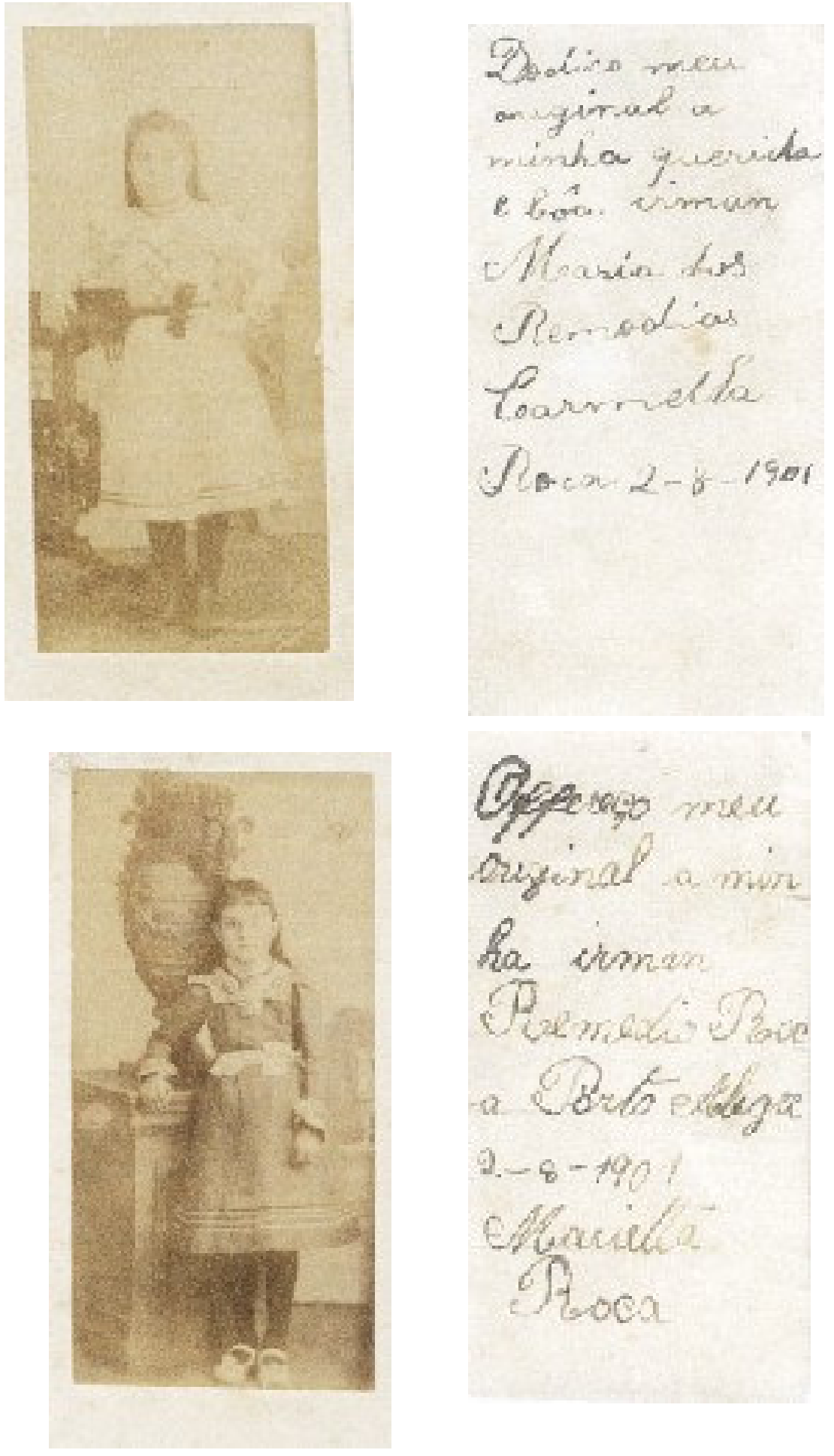

$9.8-790 ?$

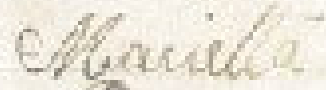

6 A

i. 1000 

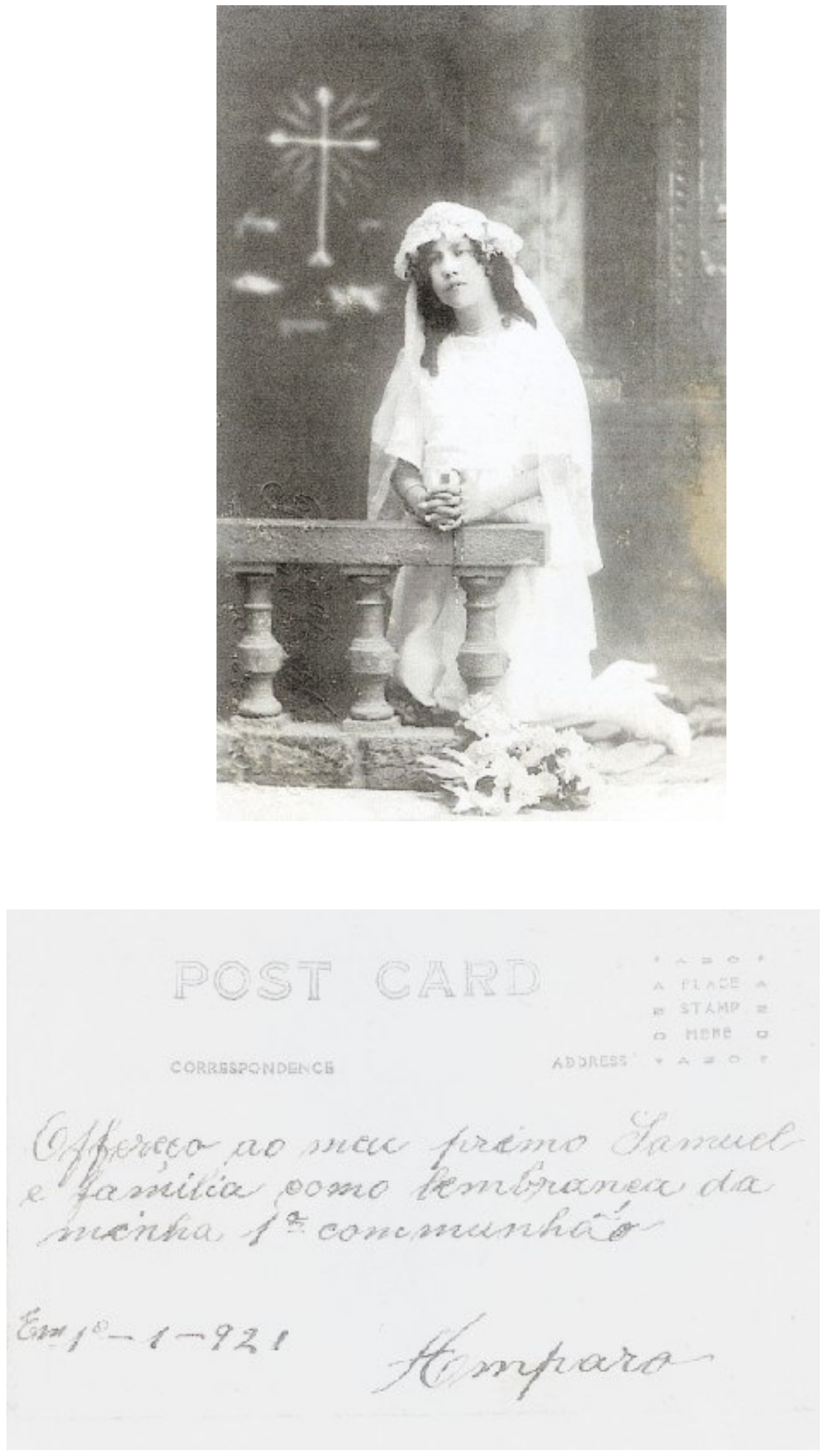

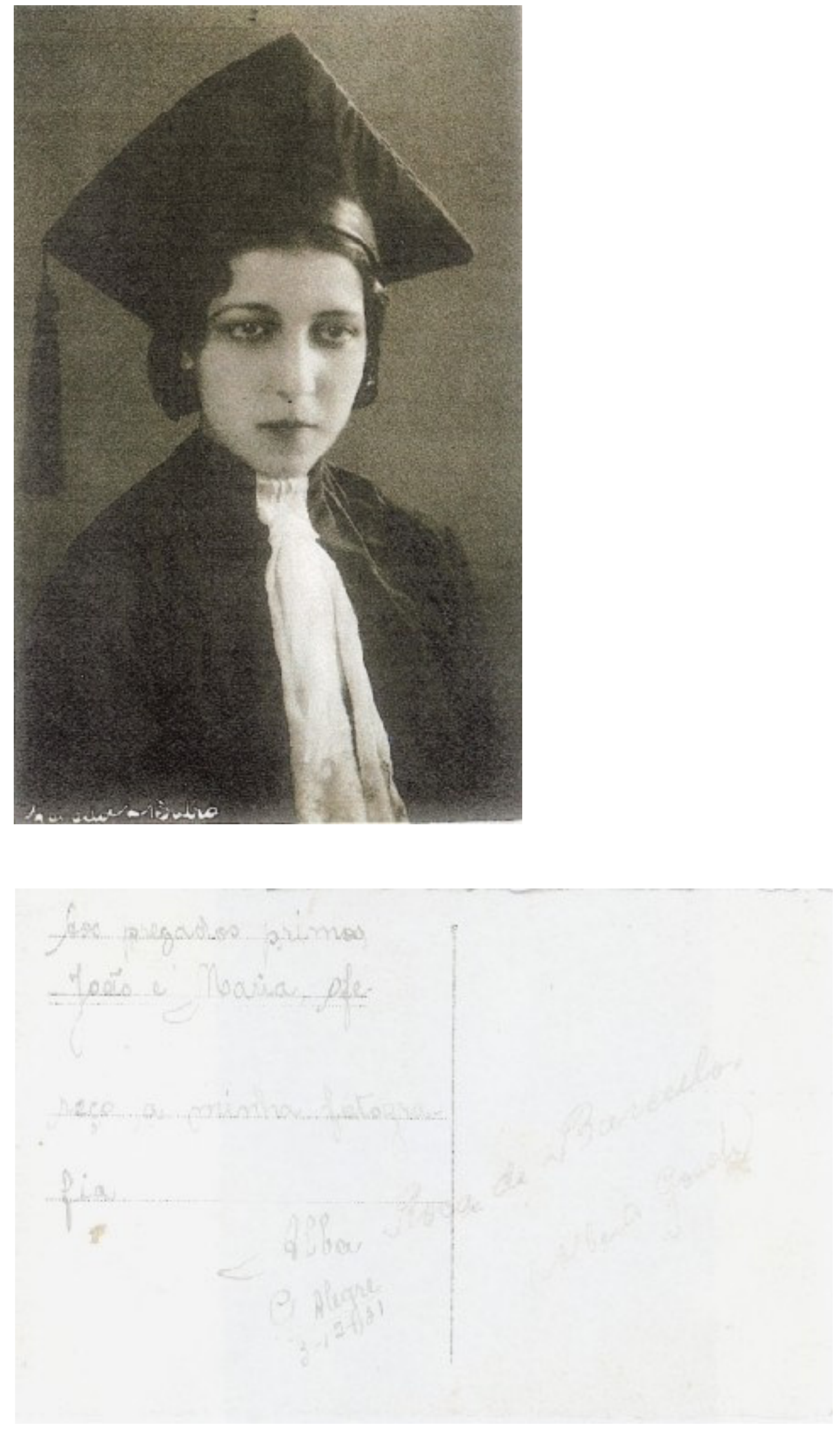


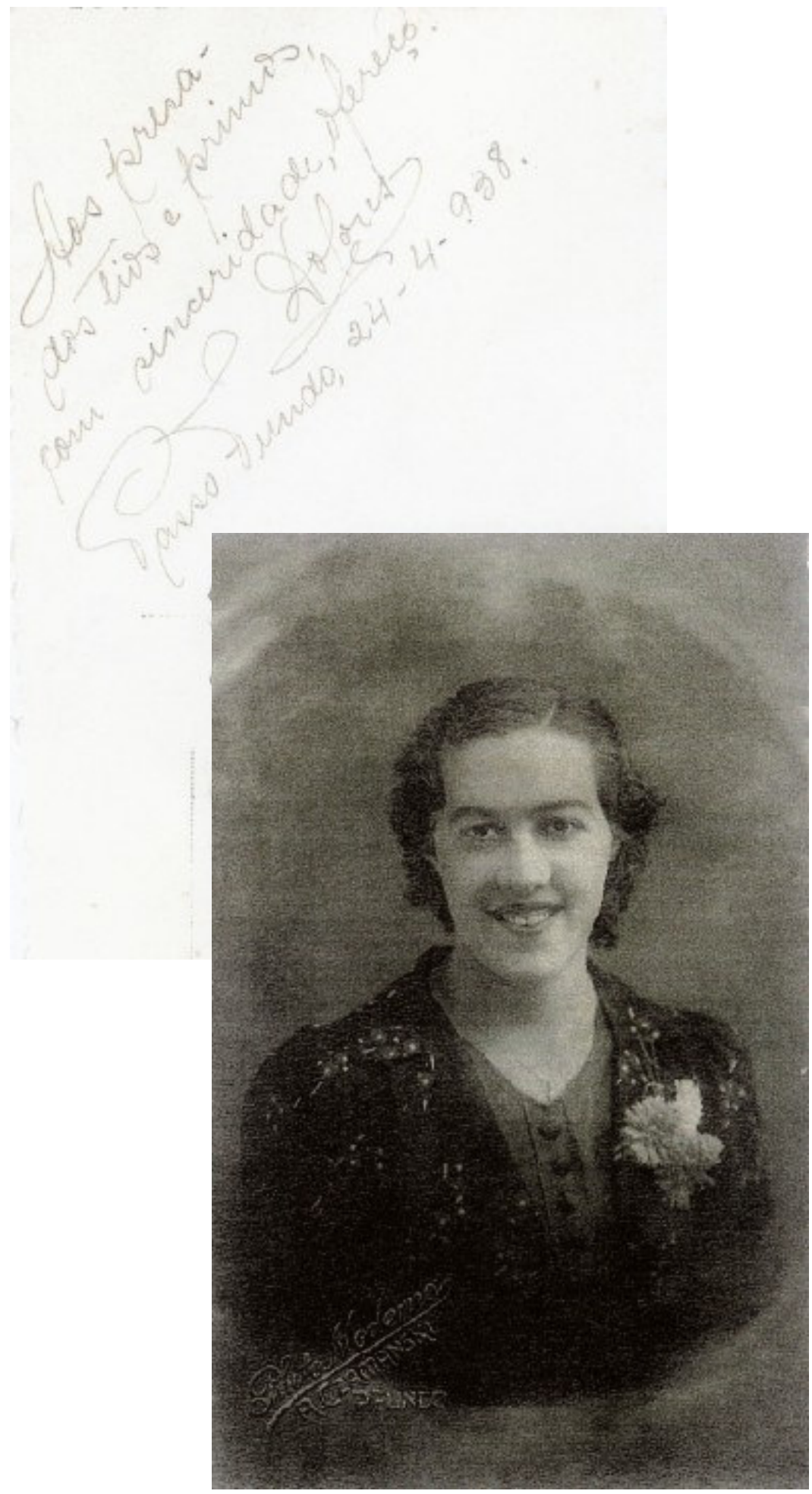




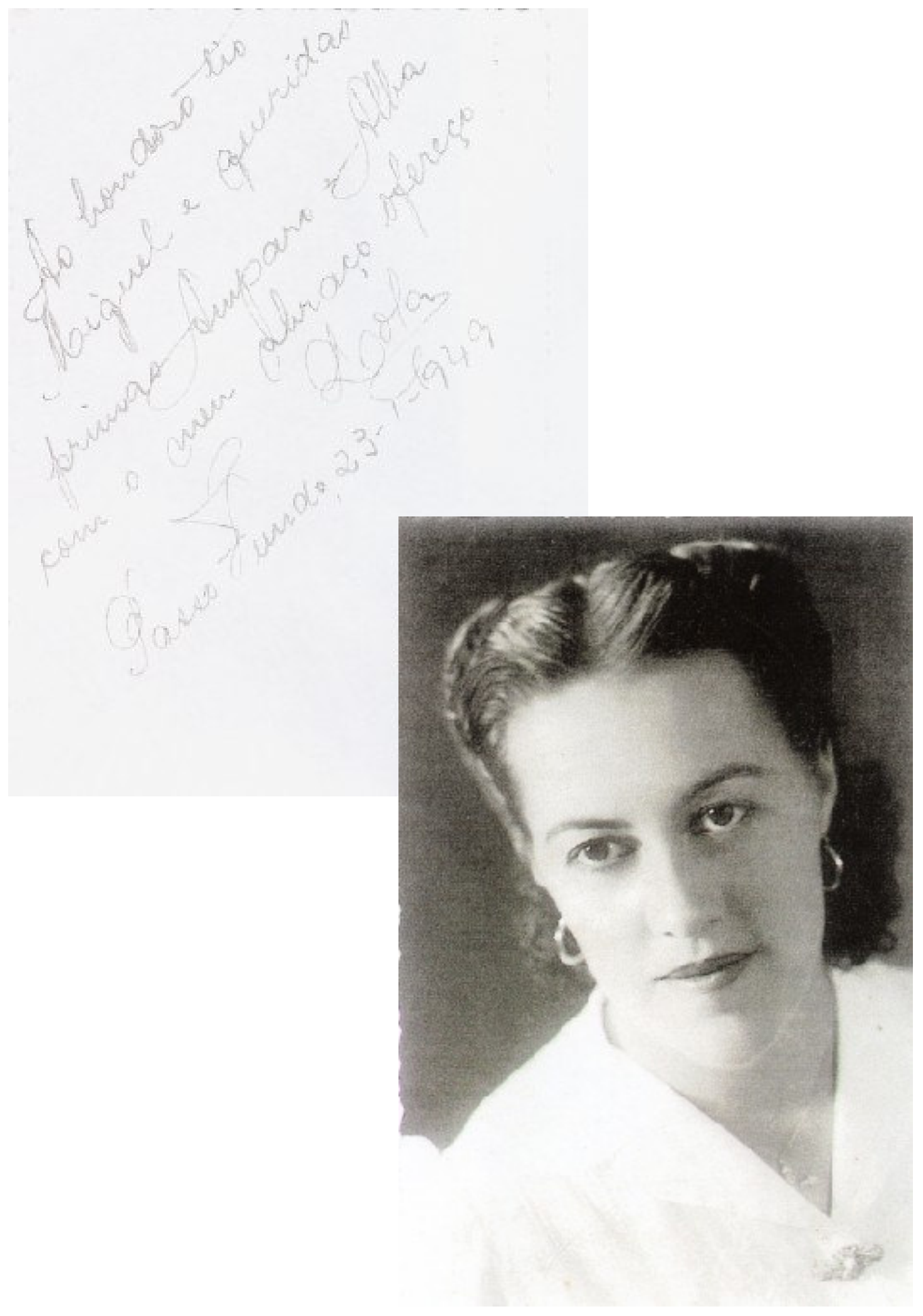



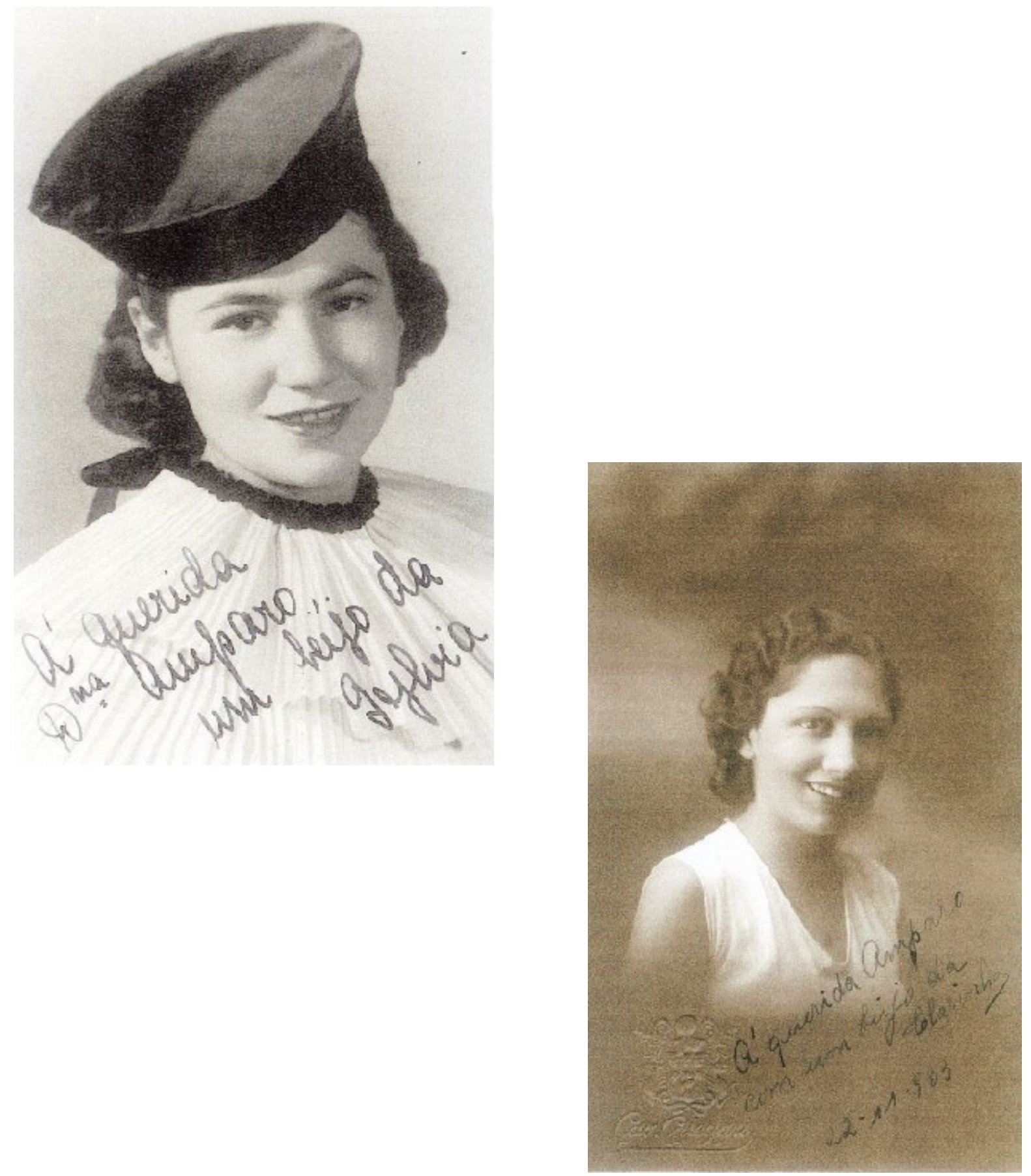
Do estúdio para a rua:

Fotografias produzidas em espaços públicos por membros da família ou por fotógrafos profissionais com máquina fotográfica portátil.
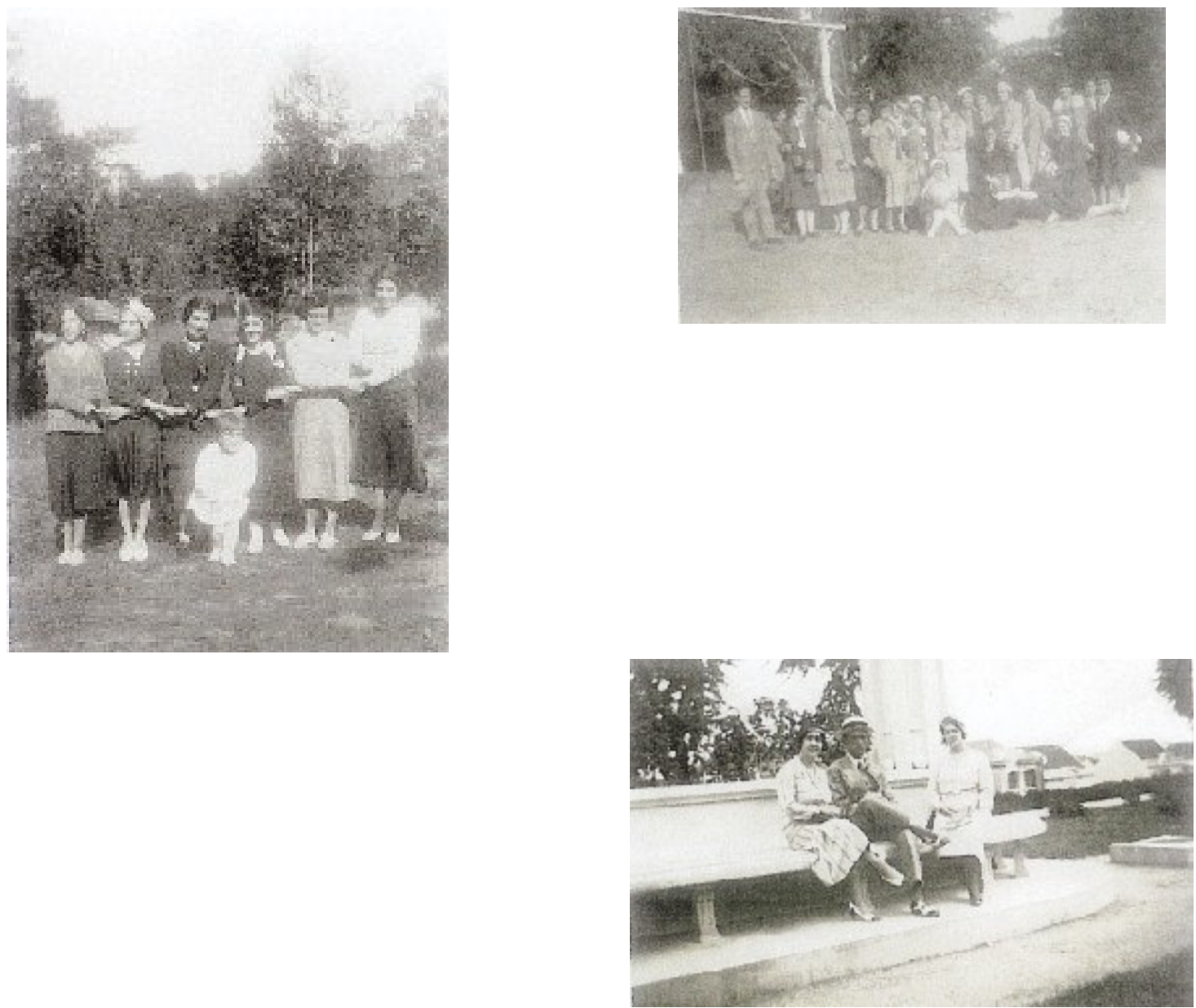

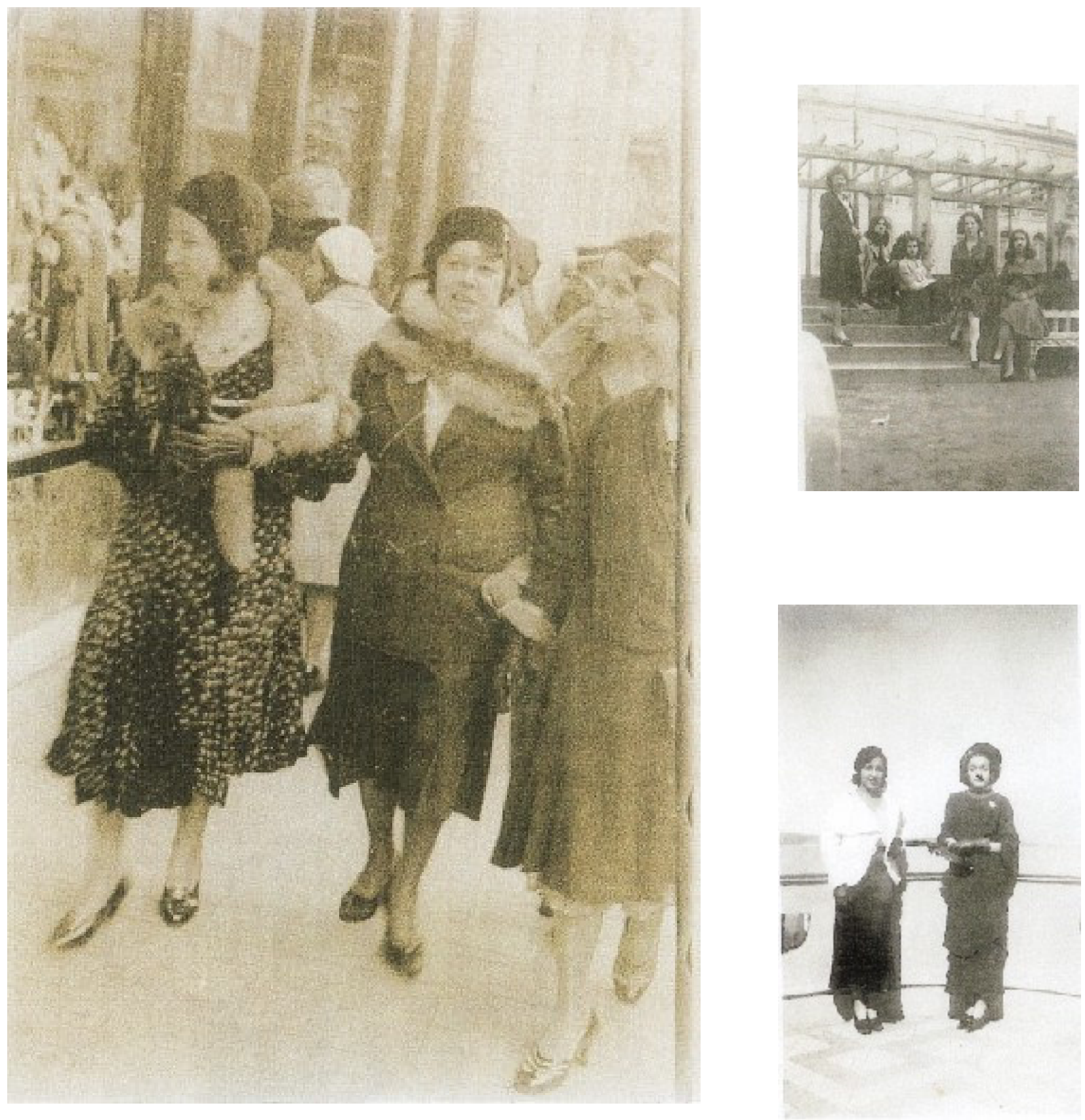



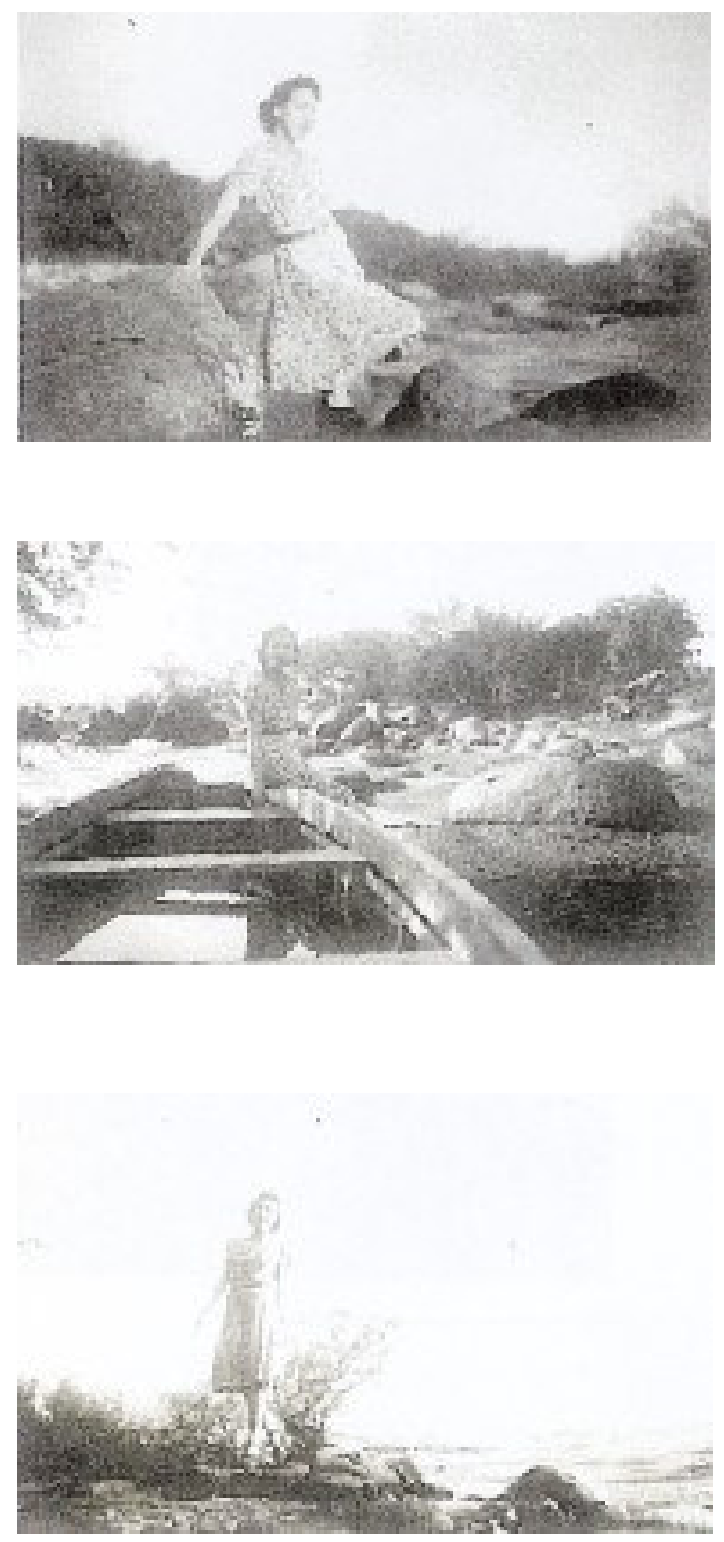
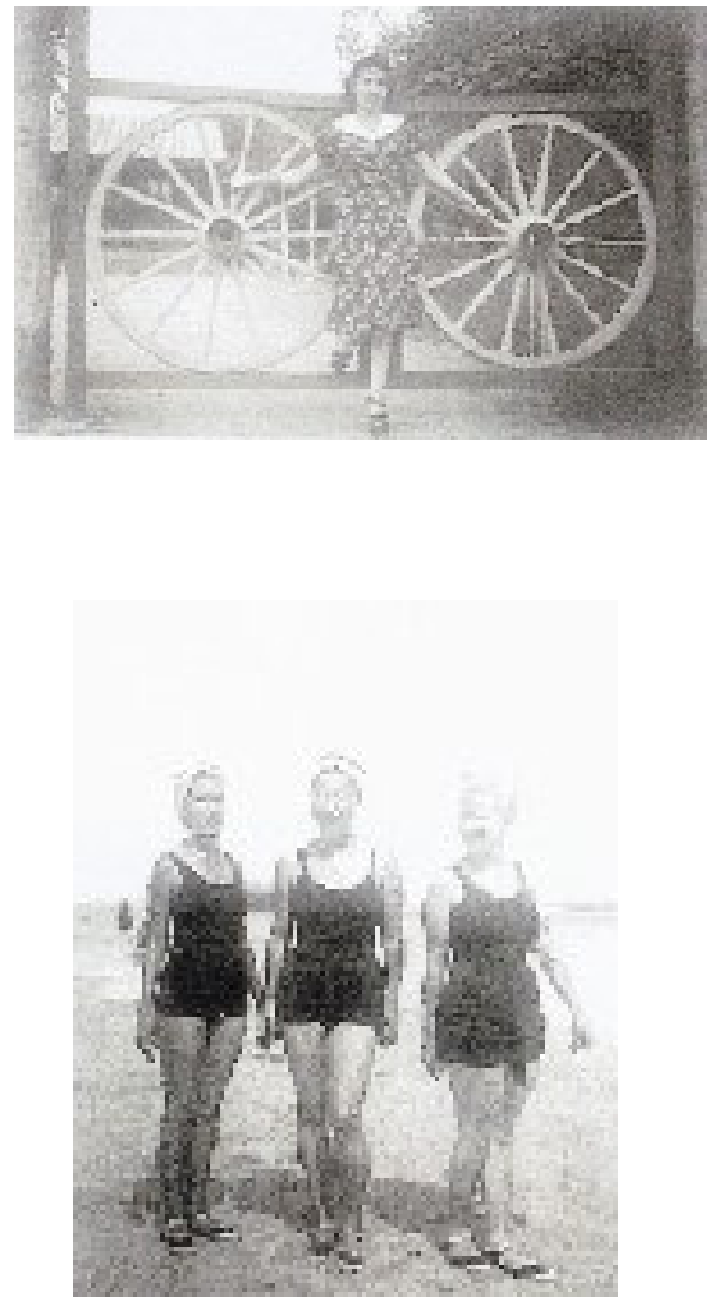

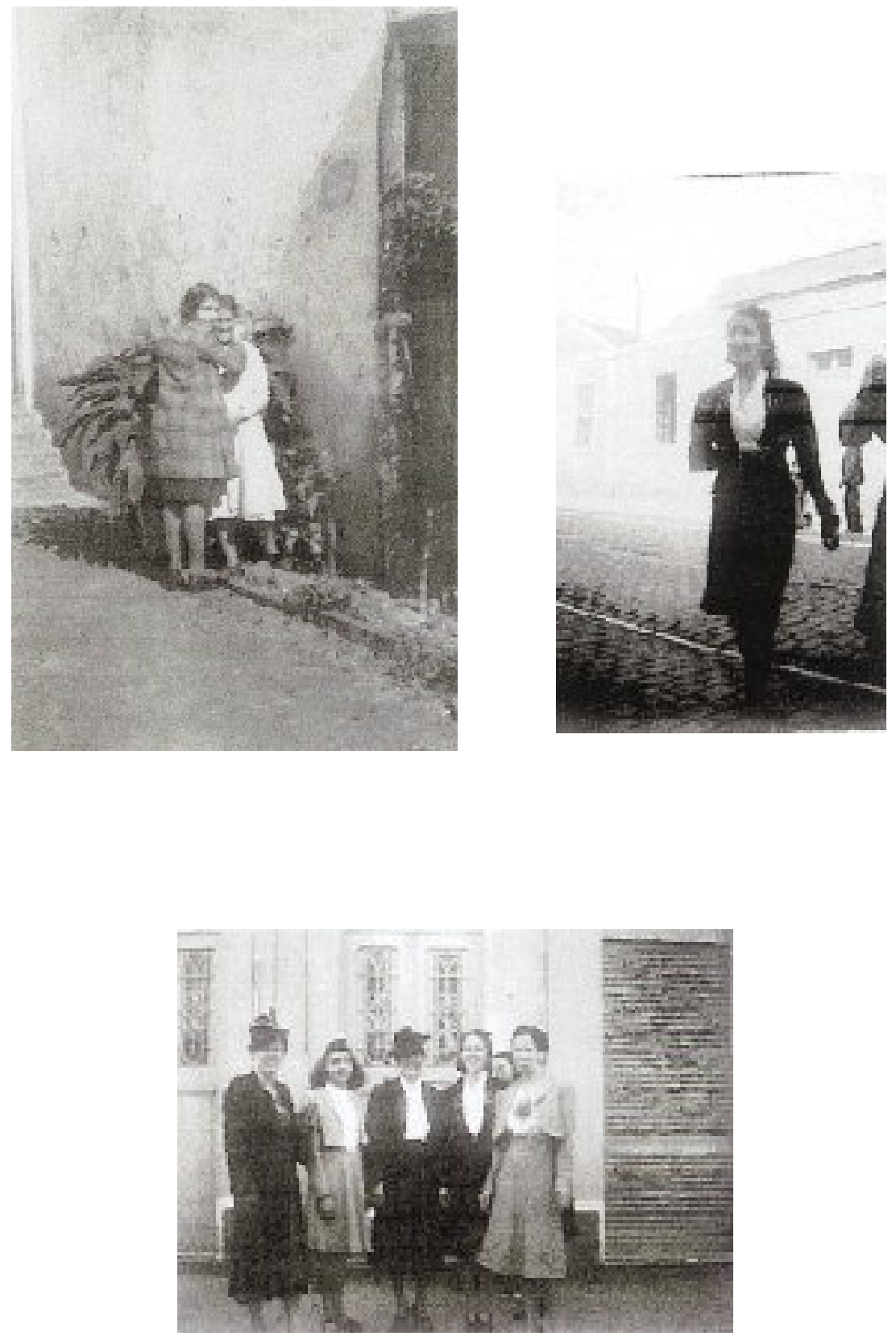


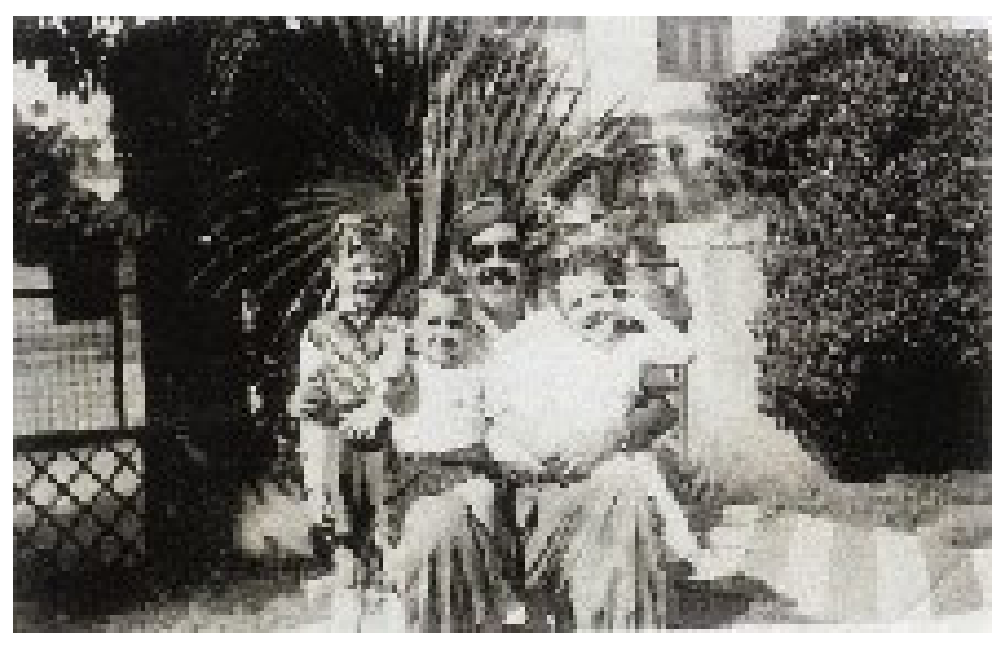


Imagens recorrentes:

Fotografia e memória
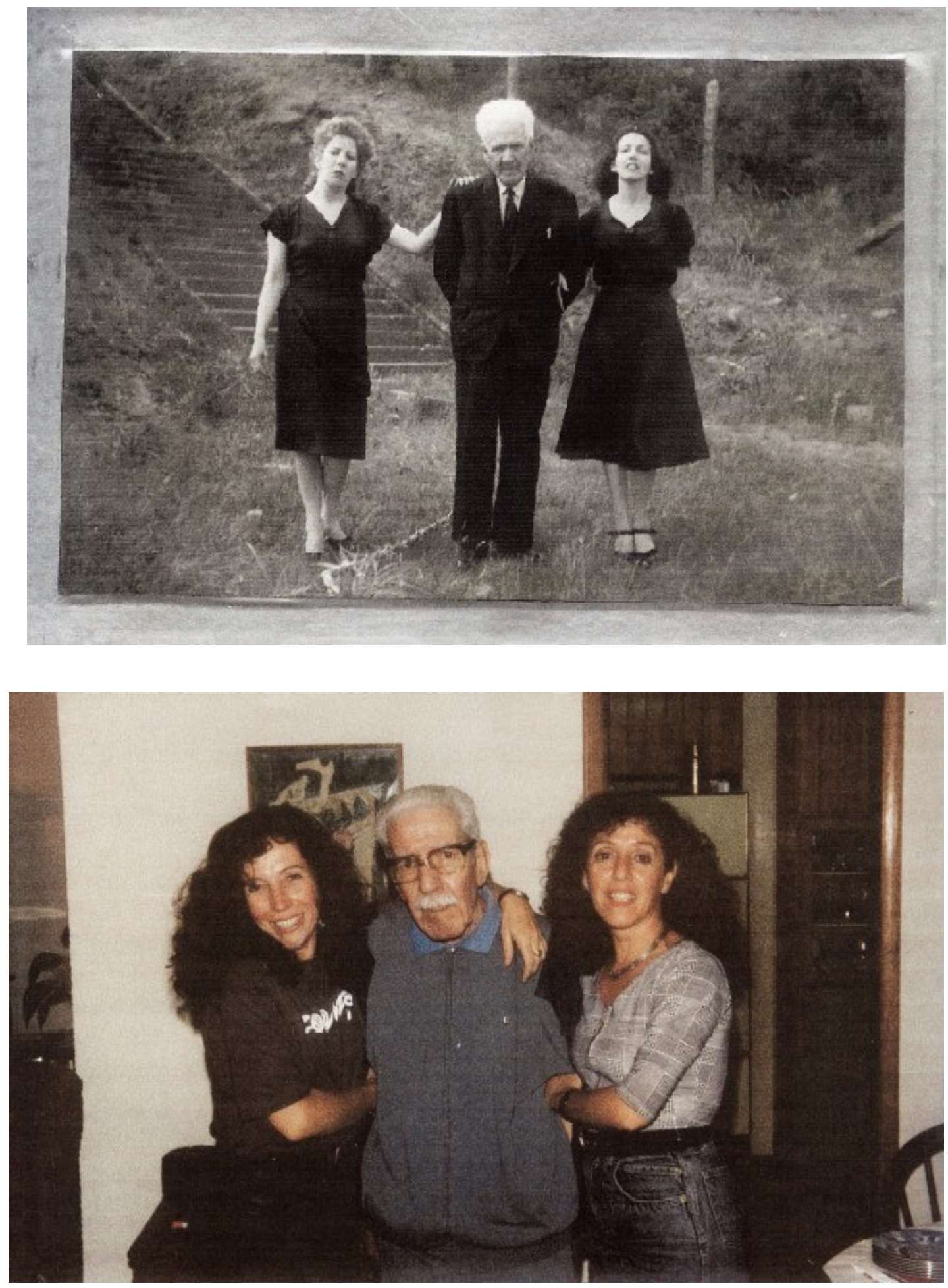


\title{
A fotografia como dado etnográfico
}

\begin{abstract}
"O que torna uma fotografia etnográfica não é necessariamente o propósito da sua produção, mas como é usada para informar etnograficamente. (...) as fotografias históricas podem ser usadas como documentos primários do mesmo modo que os próprios artefatos, e não apenas como ilustrações para informações textuais."
\end{abstract}

(Scherer, 1996: 72)

O interesse no uso da imagem nas Ciências Sociais está cada vez mais presente entre os pesquisadores. $\mathrm{Na}$ antropologia, especificamente, podemos observar a importância do uso da fotografia como técnica a partir dos trabalhos de Malinowski ${ }^{7}$. Mais tarde, Margareth Mead e Gregory Bateson, utilizam recursos audiovisuais propondo-os como método de análise ${ }^{8}$, o que faz com que sua obra Balinese Character, se torne um marco para a Antropologia Visual.

A utilização da fotografia na pesquisa antropológica se dá de diferentes formas e tem variado de acordo com a mudança dos paradigmas da disciplina e do próprio estatuto da imagem fotográfica, considerada inicialmente como a fixação de um momento da realidade e posteriormente como uma representação da mesma.

Segundo Godolphim, a utilização das técnicas audiovisuais na pesquisa antropológica pode se dar de diferentes formas: "como um instrumento de pesquisa, isto é, de produção de conhecimento etnográfico, onde a fotografia é tomada como mais uma técnica de documentação, junto com o caderno de campo e o gravador, que se usa para registrar os seus dados” ou “como elemento de interação na devolução do material fotográfico, estimulando a relação com o grupo estudado e abrindo um campo de diálogo, de expressão da memória e das reflexões dos informantes sobre as imagens devolvidas" ou ainda "como um elemento do discurso antropológico: como parte integrante de um 'texto"'(GODOLPHIM:1995, p.129-130).

Notamos que, na maioria das vezes, a captação de imagens é feita pelo próprio antropólogo ou por um fotógrafo que atue junto a este, indo a campo já com determinado conhecimento sobre a pesquisa, com o objetivo de conseguir captar as imagens necessárias aos propósitos da etnografia.

\footnotetext{
${ }^{7}$ Segundo Samain (1995), Malinowski publica em 1915 a monografia Os nativos de Mailu contendo 34 fotografias.

${ }^{8}$ Mead, Margaret. "L'anthropologie visuelle dans une discipline verbale". In: De France, Claudine. Pour une

Anthropologie Visuelle. Mouton Éditeur. Paris. La Haye. New York.
} 
Por outro lado, percebemos o pouco uso, por parte dos antropólogos, das fotografias históricas. Estamos utilizando aqui o conceito atribuído por Miriam Moreira Leite à fotografia histórica, ou seja, "aquela que nos chega às mãos pronta, tendo sido produzida há algum tempo, com relação ao momento em que é analisada pelo observador" (Leite, 2000: 15). Este tipo de material tem sido utilizado principalmente por historiadores.

É a partir dos trabalhos da historiadora Miriam Moreira Leite, sobre "retratos de família" (2000), e da antropóloga Myriam Lins de Barros, sobre "álbuns de família” (1989), que podemos sugerir que a análise deste tipo de imagens, utilizadas como um dado de pesquisa, tomam relevância no âmbito de uma Antropologia Visual no Brasil.

Segundo Lins de Barros (1989), a análise de fotografias de família permite observar como um determinado grupo social representa suas experiências e as classificam a partir do momento em que escolhem o que vai ser fotografado e o que vai ser guardado, constituindo o acervo do guardião da memória.

Para facilitar o trabalho de análise das imagens que compõem a coleção fotográfica familiar, foi criado um banco de dados onde as fotografias foram identificadas e classificadas. Este inventário contém informações sobre a produção da imagem e sobre as pessoas e os eventos retratados: ano da produção, nome do fotógrafo, lugar do estúdio, o nome da(s) pessoa(s) retratada(s), tipo de evento ou ritual registrado, elementos da composição da fotografia, o percurso da fotografia até chegar as mãos da guardiã da memória, entre outros dados. Através de relatórios, podemos selecionar as informações que queremos e/ou as fotografias. Por exemplo, podemos solicitar informações sobre todas as fotografias produzidas no período de 1896 a 1900 e o software nos apresenta os dados solicitados através de um relatório.

Os tamanhos das fotografias são variados mas é possível perceber um estilo referente a uma determinada época. É comum ter uma fotografia maior e muitas cópias menores. A maior seria exposta na parede ou em algum móvel e as menores seriam para presentear os parentes e amigos.

No material analisado foram identificadas fotografias de quatro gerações, entre as quais o número de fotos varia bastante. Da geração dos bisavós da informante há treze fotografias. A geração posterior apresenta vinte e sete fotografias. A geração do pai da informante apresenta cento e dezessete fotografias e a geração da informante possui apenas duas fotografias. 
Identificamos dois momentos distintos na coleção fotográfica analisada: O primeiro refere-se a fotografias de estúdio ou mesmo na casa do retratado mas feita por fotógrafos profissionais. O segundo momento está representado pelas imagens feitas com a máquina fotográfica da própria família ou, em poucos casos, por fotógrafos que trabalhavam na rua. Isto se dá, neste caso, a partir da década de 1920.

$\mathrm{Na}$ primeira fase, percebemos que há determinadas posturas corporais específicas, onde aparece apenas parte do corpo da pessoa fotografada. As poses são praticamente as mesmas: na maioria dos casos a fotografia é feita com o pessoa de frente, embora esta não olhe diretamente para a câmera. Poucas fotos mostram o corpo inteiro e quase sempre são de crianças. As feições são quase sempre rígidas. Apenas em algumas fotografias a face aparece descontraída e em quase nenhuma o retratado está sorrindo.

Podemos notar que há um certo cuidado na produção destas imagens pois elas mostram um momento específico da vida do retratado, servindo para legitimar o acontecimento, no caso dos rituais de passagem, ou para enviar como presente para os parentes e amigos, reafirmando os laços sociais e o pertencimento ao grupo.

Segundo Lins de Barros, a imagem permite diferentes leituras pois a lembrança do narrador é reconstruída a partir do presente, “como a de uma viagem interior e pessoal em busca da própria identidade no contexto da família. A imagem não é senão o ponto de partida para essa viagem, para um despertar de uma memória de sentimentos e emoções" (Lins de Barros, 1989: 40).

Neste sentido, a narradora confere graus diferentes de importância às fotografias que mantém consigo na coleção, demonstrando a intenção de futuramente classificá-las de acordo com esta hierarquia onde aparecem os seus ascendentes diretos, após as pessoas consideradas importantes para a história da família e por último aquelas com quem tinha um vínculo afetivo maior.

Lins de Barros também afirma que "àqueles que herdaram de seus antepassados as imagens impressas em papel, resta-lhes a curiosidade e o esforço de buscar um sentido para rostos, casas e paisagens" (Lins de Barros, 1989:39). No caso de Daisy, além desta busca de sentido para as imagens, percebemos a preocupação de conduzir parte da coleção fotográfica ao Banco de Imagens e Efeitos Visuais pois considera que estes retratos não falam apenas da sua família e das suas redes sociais, mas antes, falam de uma época e de um estilo de vida peculiar e que merece ser, além de preservado, disponibilizado a outras pessoas de forma a lhes propiciar a reconstrução de suas próprias memórias. 


\section{OS RETRATOS E O MOVIMENTO: CIRCULAÇÃO DE IMAGENS}

$\mathrm{Na}$ análise específica da imagem, buscamos observar o tipo de fotografia produzida, levando em conta se esta foi realizada em estúdio, por fotógrafo profissional, ou por máquina da própria família. Consideramos o cenário, os objetos, a postura da pessoa retratada e o tipo de evento registrado, dados relevantes para compreender o papel desta fotografia para o grupo estudado.

Partimos da análise de cento e cinqüenta e nove imagens produzidas no período de 1890 à 1952, aproximadamente. A partir da geração da informante, há o registro fotográfico de mais três gerações anteriores. Estas imagens referem-se à linhagem paterna da família de Daisy, tanto por parte da família da avó como do avô, ou seja, a família Roca e a família Barcellos respectivamente.

Estas fotografias chegaram até a informante por uma questão que ela considera circunstancial:

“... o elo foi a minha irmã, na verdade não fui eu. A tia Amparo morreu há muito tempo, setenta e oito, setenta e nove, por aí, e uma parte das coisas da Tia Amparo essa minha tia remanescente (referindo-se a tia Alba), ela deu uma parte pra minha mãe e outra ela preservou, mas estas fotografias ela não entregou pra minha mãe e nem pra nenhum de nós, ela guardou pra ela. (...) A tia Alba ficou com tudo que era da tia Amparo. (...) Quando, mais tarde tivemos que mexer nas coisas dela (por ocasião da sua morte), desmanchar a casa, aí é que apareceu esse manancial de coisas. (...) A gente selecionou, tinha muita coisa repetida."

Apesar de enfatizar este acaso, que fez com que ficasse com estas fotos de família, percebemos que há, por parte da informante, o interesse de preservar a memória do grupo através deste material, cumprindo a função de guardiã da memória.

A atividade de recolher e selecionar as fotografias fica aos cuidados de duas pessoas, da informante e da sua irmã, que demonstram o interesse em acervar uma parte deste material e doar outra para os respectivos descendentes dos retratados. Pode-se dizer que elas atuam juntas como guardiãs da memória. Aqui faremos referência apenas à Daisy pois, além de preservar a coleção fotográfica, se constituiu como a narradora da história do grupo.

Segundo Lins de Barros, o guardião da memória "está referido à família quando constrói para si e para os familiares o perfil desse papel social. Não é uma motivação individualizada que leva o colecionador a procurar, investigar, encontrar e conservar seus 
bens preciosos. Ele está imbuído de um papel que lhe confere o direito e também a obrigação de cuidar da memória do grupo familiar" (Lins de Barros, 1989: 38).

Encontra-se na coleção analisada, fotografias referentes a duas linhagens, Roca e Barcellos, além de oito retratos de jovens que eram alunos de um membro da família, tia da informante, e que mantinham relações muito estreitas com esta.

Muitas destas fotografias foram trocadas mostrando que há, neste sentido, uma circularidade das fotografias dentro do grupo familiar através destas trocas. Este sistema de reciprocidade pode ser constatado tanto na análise das fotografias, conforme o subcapítulo 1.2, quanto nas entrevistas realizadas. As fotos, assim, mostram uma rede social mais extensa, falando não só da família em questão, mas também das relações desta com outras famílias. Neste caso, a fotografia serve como aproximadora das relações entre os parentes, incluindo também no grupo, pessoas amigas sem que necessariamente tenham laços de consangüinidade.

A maioria das fotografias trocadas possuem o formato de cartão postal. Muitas apresentam dedicatória onde está indicado o nome do destinatário, um pequeno texto, a identificação do retratado e a data. Neste sentido, sugerimos que a fotografia aparece como uma reafirmação de pertencimento ao grupo, fortalecendo os laços e os valores sociais da época.

A troca de fotografias ocorria tanto entre irmãos quanto entre tios e primos. Algumas destas fotografias presenteadas acabaram voltando para a pessoa retratada, com a morte do seu possuidor, ou para um descendente direto. Percebemos isto quando Daisy se refere a um retrato de Júlio, filho de Marieta, tia de Astor, pai de Daisy:

\footnotetext{
"Eles faziam o que eu vou fazer com o filho do Júlio, dando as fotos do Júlio. Então as fotos vão e vêm e as coisas nessa família também têm esse mesmo destino."
}

As imagens podem servir como recordação, como veículo de informação sobre pessoas do grupo que não se vêem há algum tempo ou ainda como um presente enviado por ocasião de alguma data especial ou em agradecimento de alguma coisa.

Assim, podemos pensar na fotografia como instrumento utilizado para selar as relações sociais do grupo através da circulação da foto, no âmbito de um sistema de reciprocidade, de dom e contradom ${ }^{9}$. Com a morte do dono desta fotografia, percebeu-se, como mostramos acima, a tendência de devolver a imagem para a pessoa retratada ou para

\footnotetext{
${ }^{9}$ Sobre reciprocidade, ver Marcel Mauss, "Ensaio sobre a Dádiva".
} 
seus descendentes. A este respeito Lins de Barros diz que "perdas e acréscimos ao acervo ocorrem constantemente e fazem as fotos circularem no meio familiar. A lógica dessa circulação remete às construções das identidades individuais e familiares que, de alguma forma, correspondem aos diversos momentos do ciclo de vida da família. Os caminhos por onde circulam as fotos são traçados por sua doação e contradoação. As dedicatórias escritas sobre as fotos refazem estes caminhos e localizam o doador e receptor" (Lins de Barros, 1989: 38).

Chevalier, em seu artigo "Destins de cadeaux", chama a atenção sobre a importância das trocas de presentes dinamizando processos de ressocialização na nossa sociedade (Chevalier, 1998: 507).

Considerando os retratos analisados neste círculo de trocas e doações entre membros das redes familiares Roca e Barcellos, pode-se sugerir que estes são "objetospresentes" no sentido proposto por Chevalier: "l'objeto-cadeau est la matérialisation d'un lien unissant des donateurs vivants e morts" e de uma relação estabelecida entre o indivíduo e a coletividade mediatizada pelo mundo dos objetos (Chevalier, 1998: 508), e que, neste estudo, conforma uma linguagem e uma narrativa que referencia a memória coletiva destas famílias, no sentido proposto por Halbwachs, que atribui a fotografia, a eficácia de testemunho dos "quadros sociais da memória" (1990).

O familiar ou o membro da rede familiar que recebe o retrato doado por outro membro da família, compreende este ato como o de reconhecimento de pertencer à esta rede familiar, seja por parentesco consangüíneo ou por afinidade. Portanto, a circulação do retrato, é emblemático não só para identificar os membros ascendentes da família, mas para mapear os membros que de alguma maneira ou outra se relacionam com a rede familiar. Aos descendentes cabe, como no caso da nossa entrevistada, reconstituir as trajetórias destas linhagens e seus entrecruzamentos. A árvore genealógica de sua família assim, não aparece rígida, mas dinamizada por tempos vividos e contextos cotidianos que falam da identidade social e cultural dos membros de sua família ascendente e atual.

\footnotetext{
"Tinha muita coisa repetida, aí então eu imaginava assim, tinha coisas que as primas davam pra tia Alba, pra tia Amparo e pra minha avó, e pra tia Lola, pra vó Antônia. Então as vezes tinham três, quatro cópias de cada foto, com as dedicatórias pras diversas pessoas e aquilo tudo ficou concentrado, elas não botaram fora nada (...) como elas não tinham descendência, acabou que ficou na nossa mão.”
}

Quanto ao fato de algumas pessoas da família nunca aparecerem nas fotografias, isto pode ser atribuído a três fatores: Primeiro, as fotos mantidas neste grupo se referem apenas aos parentes cuja convivência era mais assídua, ou que mantinham durante algum 
tempo laços estreitos e que, ao se afastarem, utilizavam este recurso como uma maneira de recordar, outra possibilidade é que estas fotografias tenham sido devolvidas para seus donos ou descendentes e em terceiro lugar podemos sugerir que estas imagens ainda não chegaram às mãos da guardiã, estando em outras coleções.

"Meu pai não tinha quase fotografias, ele tinha fotografias que ele fez, da família no fundo do quintal, com as irmãs, com a mãe, com o pai, ele rapazote e tinha apenas uma fotografia que era aquela famosa foto de casal, do vô Miguel e da vó Maria.(...) Encontrei apenas uma fotografia do meu pai jovem, acho que todas as fotos dele estão com a minha mãe. Certamente acabarão nas minhas mãos ou nas da minha irmã."

A informante manifestou o interesse de devolver algumas fotografias para os descendentes diretos dos retratados e de conservar consigo as outras, mas ainda não sabe ao certo o destino final delas. Sobre isso se questiona:

"Estas fotos aqui foram as que nós não demos ainda, mas onde é que eu vou botar isso? Eu não vou deixar isso com os meus sobrinhos. (...) Eles não se interessam muito e nesse caso isso seria um peso."

Entre as fotografias de amigos, estão as oferecidas por alunos da tia da informante. Muitos destes alunos eram seus parentes distantes. A maioria era de classe média alta:

“... eu as vezes não sei o que que era só aluno e o que que era só parente. O que eu sei é que a minha tia era muito conhecida, não tem pessoa da geração de cinqüenta, sessenta anos que não tenha sido aluno dela na burguesia, embora ela desse aula para alguns (fica pensativa), porque ela era meio 'Robin Wood', ela cobrava dos ricos e dava aula de graça para os pobres. Ensinava as domésticas que ela tinha, a ler e escrever e eu herdei isso dela (...) eu via a tia Amparo fazer isso e achava bonito."

O fato de existirem fotografias de pessoas sem vínculo de consangüinidade junto com as fotos de família nos permite refletir sobre duas questões: primeiramente sobre a noção de família para o grupo e em segundo lugar sobre o vínculo existente entre estas diferentes famílias, que pertenciam a uma mesma classe social e que compartilhavam o mesmo hábito de trocas de retratos.

\section{FOTOGRAFIA E MEMÓRIA}

“...a atuação das imagens na memória faz com que esta revele outras imagens de episódios esquecidos e de expressões verbais que tiveram os seus significados alterados, com o decorrer do tempo."

(Moreira Leite, 2000: 129) 
Ao ver as fotografias dos seus bisavós, a informante começa a narrar a origem da família a partir destas pessoas retratadas. A avó paterna, Antônia Murillo Roca, era espanhola de Málaga/Andaluzia. Sua família veio para o Brasil por volta de 1890. Já a família do avô paterno, Miguel Fortes de Barcellos, fazia parte da aristocracia portuguesa. Esta referência parece importante para o grupo, embora parte da família dê mais importância à origem espanhola e outra ao título de nobreza dos portugueses:

"Essa memória então, assim, é como se tivesse havido uma divisão da memória da família do meu pai (...) A tia Amparo não falava nos imigrantes, falava na mãe, gostava da mãe, mas ela se interessava pela família do pai, tanto que ela mantinha relações com os parentes paternos de um modo muito estreito."

Reforça em seguida em seu depoimento o fato do seu bisavô, Manoel Roca, ter trabalhado como empreiteiro na construção da Rua da Praia, o que era considerado um orgulho para a família, mostrando a importância do valor-trabalho no grupo.

“... isso eu me criei ouvindo, era um grande orgulho assim."

O outro bisavô da informante, Antero Loreto de Barcellos, era herdeiro do título de Visconde na família. Eram conhecidos como os "Visconde de Loreto". O herdeiro direto de Antero foi seu filho Miguel. Astor, pai da narradora, por sua vez, herdou o título de Visconde de seu pai.

Esta origem aristocrática foi importante para que se manifestasse nas tias o interesse em conservar as fotografias da família. O interesse na genealogia da família e preservação de objetos e fotografias se deu em função desta origem:

\footnotetext{
“... eu acho que não haveria a valorização desse material como importante de ser preservado, talvez se perdesse. Eu acho que elas se apropriaram dessa lógica de preservação, de genealogia e tudo, e estenderam pra memória dos imigrantes. Eu acho que isso foi obra da Amparo."
}

Associa a preservação da memória familiar por parte da tia à origem aristocrática da família. Ela sempre lembrava à informante e aos seus irmãos na sua infância essa origem. Também a avó, Maria dos Remédios, valorizava muito a origem aristocrata do marido. 
Por outro lado, as espanholas falavam a língua materna em casa, ensinando os filhos e sobrinhos:

\begin{abstract}
"O meu pai tinha muitos versinhos e quadrinhas espanholas que ele guardou na memória (...) ele preservou o vínculo com a descendência espanhola através dos ditados e dos nomes das comidas e de brincadeiras que ele fazia pra nos ensinar a língua."
\end{abstract}

Por gostar destas brincadeiras e das histórias, a informante pensa que tenha se identificado mais com a linhagem espanhola da família. Também fala da grande religiosidade das espanholas, ressaltando principalmente a "tia Lola" que fazia a via sacra a pé, uma estação a cada igreja, percorrendo toda a cidade. Lola levava sempre consigo o sobrinho Astor, na época ainda criança. Daisy conta que Astor, se dizia agnóstico, falava para as pessoas que não se preocupassem com este fato, pois ele já havia rezado tudo o que tinha que rezar quando criança ao acompanhar a tia por todas as igrejas da cidade.

A informante fala sobre os santinhos que estavam guardados, através dos quais era possível traçar as relações que a família mantinha com famílias tradicionais da época e com imigrantes espanhóis e italianos.

Em relação à representação de família, podemos ressaltar o que diz a informante:

\footnotetext{
"Dos relatos do meu pai o que eu sei é que todos esses primos (...) estavam sempre juntos (...) e se batizavam uns aos outros, os primos esses todos de alguma forma são afilhados dessa geração aqui (referindo-se à geração anterior).(...) os primos do meu pai, eles se criaram muito juntos, todas as tias do meu pai moraram na casa do meu pai, que a minha avó foi a primeira a casar e o meu pobre do meu avô quando casou levou a mãe da mulher e as irmãs todas pra dentro de casa e o irmão. Todas casaram na casa dele."
}

Partindo da análise do material coletado, percebemos as transformações que ocorreram nas representações de família no grupo estudado. Através das fotografias, podemos verificar laços bastante estreitos entre tios, primos, avós e padrinhos. Todos faziam parte do que Bosi denomina 'a grande família': “A família que agora conhecemos é restrita ao grupo conjugal e aos filhos, em geral poucos; inclui cada vez menos parentes, agregados e protegidos. Uma larga parentela de tios, primos, padrinhos, rodeava de tal maneira o núcleo conjugal que ele se sentia parte de um todo maior" (Bosi, 1987: 344-345). 
Nesta grande família muitas vezes, o tio fazia o papel de pai, o primo de irmão ${ }^{10}$, e os padrinhos também tinham um papel importante. As relações entre estas pessoas eram bastante estreitas e neste sentido as fotografias se apresentam como importante elemento de troca, como regalos. Através das dedicatórias podemos traçar a trajetória das fotografias que circulavam entre os membros da rede familiar ou de amizade.

Neste sentido, encontramos muitas fotografias de alunas de Amparo, tia da informante que era professora. Além de indicar uma relação de amizade estreita com as famílias destes alunos, obtemos a informação, através da narradora, de que muitos eram parentes distantes, embora todos pertencentes a uma mesma classe social. Percebemos aqui a mesma situação que Gilberto Velho encontra na sua pesquisa sobre haver uma certa restrição a se manter relações de amizade com pessoas que pertençam a segmentos sociais muito diferentes do seu, sugerindo que há um mapa de relações preferenciais (Velho, 1987: 86).

Ao analisar as fotografias identificamos um grupo que conferia grande importância às relações de parentesco configurando dinâmicas de família extensa como tios, primos, avós. Apesar de não analisarmos fotografias recentes, percebemos através da narrativa de Daisy que atualmente a representação do que seja família para o grupo em questão se apresenta mais restrita, no sentido em que está reconhecida como composta pelo casal e pelos filhos. Os avós e tios continuam presentes mas não com a mesma intensidade ou importância de outrora onde poderiam inclusive morar juntos uns com os outros.

As fotografias selecionadas pela guardiã para compor a coleção, são aquelas das pessoas com quem mantinha uma relação afetiva maior ou que retratavam uma pessoa considerada importante dentro da linhagem familiar, o que poderia auxiliar na reconstrução das lembranças. Podemos perceber esta seleção em função da afetividade quando Daisy afirma que haviam duas fotos do mesmo tipo, de duas tias suas, Amparo e Alba. Ela tinha maior afinidade com Amparo e este fato parece determinar a opção de guardar apenas a fotografia desta, descartando a de Alba. Apesar disto, mantém outras fotografias de Alba, embora em número bem menor do que as de Amparo.

Ao analisar as fotografias, que foram dispostas sobre uma mesa, Daisy muitas vezes demonstrava surpresa ao descobrir um ou outro retrato do qual não lembrava e que dinamizava suas reminiscências. Um exemplo foi quando Daisy encontrou uma fotografia com a qual se identificou, de Maria Joaquina, irmã da sua bisavó Clara, e exclamou:

\footnotetext{
${ }^{10}$ A esse respeito ver Velho,1987.
} 
"A Joaquina! (Faz uma pausa e demonstra surpresa) Tia Amparo as vezes me chamava de Joaquina. Agora eu sei porque, eu nunca entendi porque. 'Pára Joaquina' ela dizia. Eu não sei se a minha avó usava isso como força de expressão."

Neste momento foi como se Daisy tivesse se visto na fotografia de sua antepassada, lembrando, a partir daí, das formas de tratamento utilizadas pela sua tia Amparo, comparando-a à Joaquina.

Este "trabalho" da memória converge com o "terceiro tipo de memória" analisada por Benjamin, posto que, para além da instância do inconsciente que registra traços duráveis (memória como instância conservadora) e da consciência, que se recusa a gravar traços duráveis (lembrança como instância de destruição), o autor advoga a memória involuntária, ou seja, a memória afetiva (Benjamin apud Bolle, 1984: 13).

Assim, esclarece Bolle em artigo sobre Benjamin, na era da reprodutibilidade técnica, meios como a fotografia (entre outros) permitem ampliar espantosamente a memória voluntária, mas é através da memória involuntária que Proust sugere um acesso à “essência do passado, à experiência” e, "como Proust, Benjamin dá importância especial à memória involuntária dos membros, ou seja, às imagens de memória depositadas nas mesmas posturas, nos hábitos, nos gestos”.

Analisa-se, portanto, este mergulho na infância de Daisy a partir da experiência benjaminiana descrita em seu texto Infância berlinense por volta de 1900. Willi Bolle explica a importância atribuída à memória afetiva, relação dinâmica entre passado e presente. Ressalta que “o que se procura preservar, na Infância berlinense, não são, em primeiro lugar, objetos ou artefatos, obras arquitetônicas ou urbanísticas, mas algo mais próximo da gente, uma memória da percepção, do jeito de olhar e de andar, das maneiras de comer, do despertar do sexo... Todas essas coisas naturalmente estão ligadas à percepção de um espaço. Lugares e objetos são evocados como sinais topográficos e vasos recipientes da história da sensibilidade e da formação das emoções" (BOLLE, 1984:14).

Ainda observando as fotografias, Daisy diz lembrar de coisas que lhe contaram na infância, mas demonstra uma certa preocupação com a veracidade destes acontecimentos. Algumas histórias parecem ser recorrentes no grupo:

\footnotetext{
"O calçamento da Rua da Praia que Manoel Roca (bisavô) empreitou com a prefeitura; o lugar da 'vó Maria' na família, que acolheu, quando casou, todas as irmãs e a mãe. As irmãs se formaram professoras e
} 
casaram na casa dela. Acolheu porque o vô Manoel morreu e a sua esposa ficou sozinha."

Segundo Halbwachs, "não é na história aprendida, é na história vivida que se apoia nossa memória". Para ele, "a lembrança é em larga medida uma reconstrução do passado com a ajuda de dados emprestados do presente, e além disso, preparada por outras reconstruções feitas em épocas anteriores e de onde a imagem de outrora manifestou-se já bem alterada" (Halbwachs, 1990: 60; 71).

Ao ver uma fotografia de Eduardo, irmão da sua avó Maria dos Remédios e de Dolores (Lola), filha de Eduardo, comenta:

\footnotetext{
"O tio Eduardo foi morar no interior porque ele pára de aparecer nas fotos. (...) O Eduardo, esse que morou longe, repetiu os nomes todos, botou Dolores, botou Carlos, os filhos deles todos tinham esses nomes assim, que eram os nomes dos parentes, acho que é porque foi morar longe, né?"
}

A recorrência de alguns nomes em descendentes da família se dá ao fato de servirem não só como uma homenagem aos seus parentes mas também como uma maneira de reafirmar o pertencimento ao grupo, na medida em que um determinado nome, considerado característico dos membros desta família, é repetido em diferentes gerações.

Cabe salientar aqui, o pertencimento a uma família que, em diferentes gerações, detém um poder aquisitivo e cultural característico dos grupos médios, ou como definiria Bourdieu, com posição de classe de prestígio graças ao capital cultural e financeiro do grupo familiar. Os retratos conotam este pertencimento social, atualizando uma atitude estética ou "ethos" do grupo (Bourdieu, 1965: 95). Para Pierre Bourdieu as fotografias e o fotografar são o reflexo da consciência dos sujeitos da função social que serve à sua prática. Assim, a intenção estética é também uma forma de buscar a diferenciação, a distinção (Bourdieu, 1965: 102-103).

Mas se importa aqui estar atento aos usos sociais da fotografia, e mais especificamente, sobre o lugar da fotografia para membros de classes ou grupos médios, ou sobre a forma ideologizada que os fotógrafos registram o ideal social dominante de sua época, não pretendemos ampliar uma análise do objeto deste estudo no interior de uma "economia das trocas simbólicas", para parafrasear Bourdieu. 
Gostaríamos antes de problematizar a questão da "reprodução" da memória do grupo, enquanto patrimônio familiar e social. Busca-se assim, refletir sobre o ato de doação da guardiã desta coleção a uma instituição de pesquisa sobre memória coletiva na cidade.

Por um lado, este dom diz respeito à "situação" atual do contexto familiar. Este modelo de família urbana e individualista vai se refletir no fato de não haver, na família da narradora, na nova geração dos sobrinhos da informante, alguém que demonstre interesse em assumir o papel de guardião da memória.

Neste sentido, há uma certa dificuldade em encontrar uma alternativa para o destino do acervo da guardiã da memória familiar, o que reforça o seu interesse de doar este material para um arquivo que o utilizaria para pesquisa. Estas imagens deixariam então de constituir uma coleção familiar particular, para fazer parte de um acervo público. A partir deste fato, cabe ressaltar o que diz Halbwachs, sobre a memória coletiva que "é uma corrente de pensamento contínuo, de uma continuidade que nada tem de artificial, já que retém do passado somente, aquilo que ainda está vivo ou capaz de viver na consciência do grupo que a mantém. Por definição, ela não ultrapassa os limites deste grupo. Quando um período deixa de interessar ao período seguinte, não é um mesmo grupo que esquece uma parte de seu passado: há, na realidade, dois grupos que se sucedem” (1990: 81-82).

Sugerimos que a falta de uma pessoa que se responsabilize pela coleção fotográfica das famílias Roca e Barcellos, no formato em que é apresentada atualmente por Daisy, não implica no fato de haver uma perda da memória do grupo. O que ocorre é que outras imagens vão sendo incorporadas e acabarão constituindo futuramente outras coleções formadas pelos descendentes mais jovens que passam a reconstruir as lembranças a partir de suas referências. Esta nova coleção poderá ou não conter alguns retratos da coleção atual e possivelmente terá uma pessoa que se responsabilize por ela. Mas neste caso, como mostra Halbwachs, podemos considerar que é um novo grupo que está sucedendo o anterior.

No caso do Banco de Imagens e Efeitos Visuais (PPGAS, UFRGS), projeto em que atuo desde 1997 como bolsista de Iniciação Científica, este "prestígio" e "honra” de acervar e analisar os retratos da família da doadora, insere o campo da pesquisa científica e os próprios pesquisadores, num sistema de trocas sociais, num sistema de "circularidade" de objetos com sentido pois que narram as experiências individuais e coletivas "onde pulsa a vida" como ensinou Walter Benjamin, e testemunhou a magia de viver no social como inscreveu Marcel Mauss. 


\section{Considerações finais}

Este estudo consistiu na análise de retratos de família, reinterpretados a partir da narrativa da guardiã da memória familiar. Ao nos apoiar numa coleção de fotografias para estudar o tema memória e família, percebemos a importância da utilização conjunta destes dois recursos: os retratos de família e a narrativa da informante. Isto se dá pelo fato das fotografias acionarem as lembranças da narradora, permitindo a reconstrução do passado, possibilitando a contextualização das imagens.

A fotografia contém em si uma série de informações a partir das quais podemos refletir sobre as representações de família para o grupo, a importância da fotografia na reconstrução da memória e a forma como estas imagens servem de base para um sistema de reciprocidade onde os laços familiares e o sentimento de pertencimento ao grupo são reafirmados.

No entanto, percebemos que ao utilizar fotografias históricas, torna-se necessário obter informações de alguém que conheça tanto as pessoas retratadas quanto o contexto onde foram produzidas as imagens. Neste sentido a figura da narradora da história familiar torna-se fundamental. É através da sua narrativa que várias informações, não perceptíveis através da análise exclusiva da fotografia, acabam por compor um cenário mais amplo permitindo compreender a história familiar.

A partir do momento em que Daisy passa a guardar a coleção de fotografias da família, ela acaba assumindo a responsabilidade de atuar em nome da memória do grupo, definindo quais as fotografias e objetos serão guardados e de que maneira este acervo vai sendo reformulado, incorporando novos materiais e descartando outros, selecionando as imagens que testemunharão a trajetória familiar.

Sugerimos aqui que a falta de um sucessor que assuma o papel de guardião da memória familiar, conforme aponta Daisy, reforça o seu interesse em doar as fotografias para um arquivo público. Ao deixar de pertencer a uma coleção particular para integrar um acervo maior, as fotografias das famílias Roca e Barcellos passariam a representar não apenas a história deste grupo, mas também a história das famílias de Porto Alegre que viveram em uma determinada época. As imagens tornariam-se impessoais na medida em que deixariam de falar somente da pessoa retratada, acionando as lembranças de seus familiares, para falar também de outras pessoas que viveram naquele mesmo contexto, reconstruindo a memória da própria cidade. 
Ao doar a coleção fotográfica para um núcleo de pesquisa ou um arquivo público, Daisy desloca os retratos de uma circularidade familiar, introduzindo esta coleção no âmbito de uma comunidade acadêmica, que tem por objetivo a reflexão científica sobre os dados de pesquisa coletados. Ou seja, os retratos doados, no contexto da Universidade, passam a ser apropriados pelos pesquisadores enquanto um objeto científico de análise. Há portanto, uma ressemantização dos significados possíveis desta coleção, o que significa dizer que ocorre uma ampliação da mensagem destas imagens, não mais restritas à circunferência do mundo doméstico privado, onde sua eficácia narrativa se situava em poder narrar a memória coletiva dos membros dos grupos familiares Roca e Barcellos, para agora serem apropriados como uma narrativa mais ampla de famílias moradoras de Porto Alegre.

\section{Referências}

ALVES, Hélio Ricardo. "A fotografia em Porto Alegre: o século XIX”. In: Achutti, Luiz Eduardo Robinson (org.) Ensaios sobre o fotográfico. Unidade Editorial. PMPA. Porto Alegre. p. 09-22. 1998.

ARANTES, Antônio Augusto. "Pais, padrinhos e o Espírito Santo: um reestudo do compadrio". In: Colcha de retalhos - estudos sobre a família no Brasil. p. 193-204. Ed. Brasiliense. SP. 1982.

BOLLE, Willi. "Cultura, patrimônio e preservação". In: Arantes, Antônio Augusto. (org.) Produzindo o passado - Estratégias de construção do patrimônio cultural. Brasiliense. SP. p. $11-23.1984$.

BOURDIEU, Pierre. "Un art moyen - essai sur les usages sociaux de la photographie". Deuxième édition. Les Éditions de Minuit. 1965.

BRANDÃO, Carlos Rodrigues. "Parentes e parceiros (relações de produção e relações de parentesco entre camponeses de Goiás". In: Colcha de retalhos - estudos sobre a família no Brasil. p. 91-135. Ed. Brasiliense. SP. 1982.

BOSI, Ecléa. "Memória e Sociedade: Lembrança de Velhos". 2 ed. São Paulo. T.A.Queiroz: Editora da Universidade de São Paulo, 1987.

CARVALHO, Áurea Maria de Freitas. "Fotografia como fonte de pesquisa". Fundação Nacional Pró-Memória. Museu Imperial. RJ, 1986.

CHEVALIER, Sophie. "Intérieurs domestiques urbains en France et en Angleterre". In: Horizontes Antropológicos, Porto Alegre, ano 6, n. 13, p. 113-125, junho 2000.

"Destins de cadeaux". In Revue Ethnologie française, les cadeau: a quel prix? Armand Colin, - octobre - décembre. P. 506 a 514. 1998.

COLLIER JR. John. "Antropologia Visual: a fotografia como método de pesquisa". Coleção Antropologia e Sociologia. E.P.U. Editora da Universidade de São Paulo. SP, 1973.

DA MATTA, Roberto. "A família como valor: Considerações não familiares sobre a família à brasileira". In: Almeida, Ângela Mendes (org). Pensando a família no Brasil: Da colônia à modernidade. Rio de Janeiro. Espaço e Tempo, UFRRJ, p. 115-136. 1987.

ECKERT, Cornelia; ROCHA, Ana Luiza Carvalho. "Os jogos da memória". Iluminuras n. 12, Banco de Imagens e Efeitos Visuais/PPGAS/UFRGS, Porto Alegre, 2000. 
ECKERT, Cornelia; BARROS, Alfredo; GASTALDO, Édison; GUTERRES, Liliane; RODOLPHO, Adriane. "Inventariando a grafia da luz nas dissertações de mestrado do Programa de Pós-Graduação em Antropologia Social/UFRGS". In: Revista Horizontes Antropológicos, volume 7, Porto Alegre, PPGAS, UFRGS, p. 316 - 349. 1997.

EDWARDS, Elizabeth. "Antropologia e Fotografia". In: Cadernos de Antropologia e Imagem 2. UERJ, RJ. p. 11-28. 1996.

FERREIRA, Maria Letícia Mazzucchi. "Olhares fixos na imensidão do tempo: Fotografia e lembrança". In: Cadernos de Antropologia e Imagem 2. UERJ, RJ. p. 115-126. 1996.

GODOLPHIM, Nuno. "A fotografia como recurso narrativo: problemas entre a apropriação da imagem enquanto mensagem antropológica". In: Horizontes Antropológicos Porto Alegre, ano 1, n. 2, p. 125-142, 1995.

GURAN, Milton. "Fotografia e pesquisa antropológica". Caderno de Textos. Antropologia Visual. Museu do Índio.

HALBWACHS, Maurice. “A memória coletiva”. São Paulo. Ed. Vértice, 1990.

JONAS, Irène. "Mentira e verdade do álbum de fotos de família". In: Cadernos de Antropologia e Imagem 2. UERJ, RJ. p. 105-114. 1996.

KOURY, Mauro Guilherme Pinheiro. "Relações Imaginárias: a fotografia e o real". In: Achutti, Luiz Eduardo Robinson (org.) Ensaios sobre o fotográfico. Unidade Editorial. PMPA. Porto Alegre. p. 72-78. 1998.

LANNA, Marcos P. D. "A dívida divina - troca e patronagem no nordeste brasileiro". Editora da UNICAMP. Campinas/SP. 1995.

LEITE, Miriam Moreira. "Retratos de Família". 2.ed. São Paulo: Editora da Universidade de São Paulo, 2000.

“Texto visual e texto verbal". In: Feldman-Bianco, Bela \& Leite, Miriam Moreira (orgs): Desafios da imagem: Fotografia, iconografia e vídeo nas Ciências Sociais. p.37-49. Papirus. SP: 1998.

LINS DE BARROS, Myriam Moraes. “Autoridade \& Afeto: avós, filhos e netos na família brasileira". Jorge Zahar Editor. Rio de Janeiro, 1987.

Janeiro. Vértice, 1989.

"Memória e família". Estudos Históricos, n.3, v.2. p. 29-42. Rio de

"O passado no presente: aos 70 falando do Rio de Janeiro". In:

Cadernos de Antropologia e Imagem, n. 4. UERJ, RJ. p. 91-105. 1995.

NIEMEYER, Ana Maria. "Um outro retrato: imagens de migrantes favelados". In: Feldman-Bianco, Bela \& Leite, Miriam Moreira (orgs): Desafios da imagem: Fotografia, iconografia e vídeo nas Ciências Sociais. p.225-264. Papirus. SP: 1998.

PINNEY, Christopher. "A história paralela da antropologia e da fotografia“. In: Cadernos de Antropologia e Imagem 2. UERJ, RJ. p. 29-52. 1996.

SAMAIN, Etienne. "Ver e dizer na tradição etnográfica: Bronislaw Malinowski e a fotografia". In: Horizontes Antropológicos Porto Alegre, ano 1, n. 2, p. 19-48, 1995.

SANTOS, Alexandre Ricardo. "A fotografia e as representações do corpo contido (Porto Alegre 1890-1920). UFRGS/Instituto de Artes. Porto Alegre, 1997.

"O gabinete do Dr. Calegari: considerações sobre um bem-sucedido

fabricante de imagens". In: Achutti, Luiz Eduardo Robinson (org.) Ensaios sobre o fotográfico. Unidade Editorial. PMPA. Porto Alegre. p. 23-37. 1998.

SCHMIDT, Benito Bisso. "Anita Xavier da Costa: Memórias da filha de um pioneiro do socialismo no Rio Grande do Sul - Da fogueira das lembranças ao álbum de recordações". In: Horizontes Antropológicos, Porto Alegre, ano 5, n. 12, p. 167-182, dezembro 1999. 
SCHERER, Joanna. "Documento fotográfico: fotografias como dado primário na pesquisa antropológica". In: Cadernos de Antropologia e Imagem, ano 2, n. 3. UERJ, RJ. p. 69-83. 1996.

VELHO, Gilberto. "Família e subjetividade”. In: Almeida, Ângela Mendes (org). Pensando a família no Brasil: Da colônia à modernidade. Rio de Janeiro. Espaço e Tempo, UFRRJ, p. 79-87. 1987.

\section{Índice das fotografias apresentadas:}

\section{Fotografias de família}

\section{As diferentes gerações das famílias Roca Barcellos}

Na página 6 da esquerda para a direita no alto:

Manoel Roca.

Antônia Murillo Roca.

Na página 6 da esquerda para a direita embaixo:

Clara Pereira Fortes de Barcellos.

Antero Loreto de Barcellos.

Na página 7:

As cinco espanholas Roca: Dolores (Lola), Maria dos Remédios, Marieta, Carmem (Carmella) e Maria Francisca (Paquita).

Na página 8 da esquerda para a direita:

Maria Joaquina Pereira Fortes.

Miguel de Barcellos e Maria Joaquina Pereira Fortes.

Na página 8, embaixo:

Clara Pereira Fortes de Barcellos.

Na página 9 da esquerda para a direita:

Clara Fortes de Barcellos (1890).

Eduardo Roca.

Na página 10:

Miguel Fortes de Barcellos e Maria dos Remédios Roca de Barcellos.

Na página 11:

Ao alto, Clara Pereira Fortes de Barcellos.

À direita Miguel Fortes de Barcellos.

Abaixo Astor Roca de Barcellos.

Na página 12 da esquerda para a direita:

Clara e Morena Fortes de Barcellos, filhas de Clara e Antero.

Lucilia Morena de Barcellos e Isolina Branca de Barcellos, filhas de Constantino Fortes de Barcellos e sobrinhas de Clara e Morena Fortes de Barcellos. Fotografia datada de 02/01/1912.

Na página 13 ao alto:

Dolores Roca (Lola), filha de Eduardo Roca, sobrinha de Dolores Murillo Roca. Abaixo, Dolores Murillo Roca (Lola).

Na página 14:

À esquerda Alba Roca de Barcellos. Fotografia datada de 03/12/1931.

À direita Alberto Gosch, casado com Alba. (1955).

Na página 15:

À esquerda Amparo Roca de Barcellos. 
À direita Alba Roca de Barcellos.

Circulação de imagens: reciprocidade através da troca de retratos

Na página 16, no alto:

Carmem Roca (Carmella - 1901).

Embaixo, Marieta Roca (1901).

Na página 17:

Amparo Roca de Barcellos (1921).

Na página 18:

Alba Roca de Barcellos (1931).

Na página 19:

Dolores Roca, filha de Eduardo Roca (1938).

Página 20:

Dolores Roca (1949).

Página 21:

À esquerda Sylvia (1942).

À direita Clarinha (1933).

Ambas as fotografias referem-se a alunas de Amparo Roca Barcellos.

Do estúdio para a rua: fotografias produzidas em espaços públicos por memvors da família ou por fotógrafos profissionais com máquina fotográfica portátil

Página 22:

Fotografias de passeios de colegas da escola de Amparo e Alba e amigos da família Roca de Barcellos.

Página 23:

Dolores Roca passeando com amigas na Rua da Praia.

Página 24:

Piqueniques das famílias Roca e Barcellos.

Página 25:

Passeios de Alba Roca de Barcellos.

Página 26:

Fotografias tiradas no pátio da casa da família Barcellos e nas ruas de Porto Alegre.

Página 27:

No alto Amparo, Miguel e Alba.

Abaixo Tânia, Astor e Daisy. 